\title{
Dorsal Raphe Serotonin Neurons in Mice: Immature Hyperexcitability Transitions to Adult State during First Three Postnatal Weeks Suggesting Sensitive Period for Environmental Perturbation
}

\author{
Benjamin D. Rood, ${ }^{1,2}$ Lyngine H. Calizo, ${ }^{1}$ David Piel, ${ }^{1}$ Zachary P. Spangler, ${ }^{1}$ Kaitlin Campbell, ${ }^{2}$ and Sheryl G. Beck ${ }^{1,2}$ \\ ${ }^{1}$ Department of Anesthesiology and Critical Care, Children's Hospital of Philadelphia, Philadelphia, Pennsylvania 19104, and ${ }^{2}$ Department of \\ Anesthesiology, University of Pennsylvania Perelman School of Medicine, Philadelphia, Pennsylvania 19104
}

\begin{abstract}
Trauma during early life is a major risk factor for the development of anxiety disorders and suggests that the developing brain may be particularly sensitive to perturbation. Increased vulnerability most likely involves altering neural circuits involved in emotional regulation. The role of serotonin in emotional regulation is well established, but little is known about the postnatal development of the raphe where serotonin is made. Using whole-cell patch-clamp recording and immunohistochemistry, we tested whether serotonin circuitry in the dorsal and median raphe was functionally mature during the first 3 postnatal weeks in mice. Serotonin neurons at postnatal day 4 (P4) were hyperexcitable. The increased excitability was due to depolarized resting membrane potential, increased resistance, increased firing rate, lack of $5-\mathrm{HT}_{1 \mathrm{~A}}$ autoreceptor response, and lack of GABA synaptic activity. Over the next 2 weeks, membrane resistance decreased and resting membrane potential hyperpolarized due in part to potassium current activation. The $5-\mathrm{HT}_{1 \mathrm{~A}}$ autoreceptor-mediated inhibition did not develop until P21. The frequency of spontaneous inhibitory and excitatory events increased as neurons extended and refined their dendritic arbor. Serotonin colocalized with vGlut 3 at P4 as in adulthood, suggesting enhanced release of glutamate alongside enhanced serotonin release. Because serotonin affects circuit development in other brain regions, altering the developmental trajectory of serotonin neuron excitability and release could have many downstream consequences. We conclude that serotonin neuron structure and function change substantially during the first 3 weeks of life during which external stressors could potentially alter circuit formation.
\end{abstract}

\section{Introduction}

More than $25 \%$ of the population will likely develop an anxiety or mood disorder at some point in their lives (Kessler et al., 2005), and stressful early life experiences (e.g., childhood trauma) are considered to be a primary risk factor (Agid et al., 1999; De Bellis et al., 1999; De Bellis and Thomas, 2003). Understanding how the brain might be altered by early life events is critical to addressing this issue. Serotonin [5-hydroxytryptomine(5-HT)] likely plays a critical role in the etiology of anxiety and mood disorders as drugs that affect 5-HT physiology (e.g., selective serotonin reuptake inhibitors) are among the most efficacious in treating such disorders (Koen and Stein, 2011) and have anxiolytic properties in rodent anxiety models (Carr and Lucki, 2011). In mice, genetic disruptions of 5-HT production (e.g., knockout of the critical transcription factor Pet-1) or specific 5-HT receptors, especially

\footnotetext{
Received April 8, 2013; revised Feb. 21, 2014; accepted Feb. 25, 2014.

Author contributions: B.D.R., L.H.C., and S.G.B. designed research; B.D.R., L.H.C., D.P., Z.P.S., and K.C. performed research; B.D.R. and S.G.B. analyzed data; B.D.R. and S.G.B. wrote the paper.

The authors declare no competing financial interests.

This study was supported by National Institute of Mental Health Grants R01 MH0754047, R21 MH099488, and RC1MH089800 to S.G.B.

Correspondence should be addressed to Sheryl G. Beck, 3615 Civic Center Boulevard 402c Abramson Research Center, Children's Hospital of Philadelphia, Philadelphia, PA 19104. E-mail: becks@email.chop.edu.

DOI:10.1523/JNEUROSCI.1498-13.2014

Copyright $\odot 2014$ the authors $\quad 0270-6474 / 14 / 344809-13 \$ 15.00 / 0$
}

5- $\mathrm{HT}_{1 \mathrm{~A}}$, result in an anxious phenotype (Ramboz et al., 1998; Hendricks et al., 2003; Richardson-Jones et al., 2010; Donaldson et al., 2014). Closer examination of the $5-\mathrm{HT}_{1 \mathrm{~A}} \mathrm{KO}$ model demonstrated that anxiety-like behavior is increased when $5-\mathrm{HT}_{1 \mathrm{~A}}$ autoreceptors are absent either throughout life or just in the second through third weeks of life (Lo Iacono and Gross, 2008; Richardson-Jones et al., 2010; Donaldson et al., 2014), suggesting a developmental role for 5-HT and associated receptors in early life that are required for proper emotional development.

Current knowledge of 5-HT development centers around prenatal studies from rats and mice showing that 5-HT is produced in the embryonic raphe as early as embryonic day 12 (E12) to E13, 5-HT projections reach most parts of the forebrain by E18-E19, and the subfields of the dorsal raphe (DR) are identifiable at birth (Lidov and Molliver, 1982; Wallace and Lauder, 1983; Aitken and Törk, 1988; Hawthorne et al., 2010). Despite the apparent maturity of the perinatal 5-HT system, little is known about the structure and function of the raphe after birth. This is a critical gap as 5 -HT plays a role in postnatal development in brain regions such as the prefrontal cortex and hippocampus (Benekareddy et al., 2010; Migliarini et al., 2013), and the critical period for $5-\mathrm{HT}_{1 \mathrm{~A}}$ dependent development of anxiety phenotype occurs in the first few weeks of life (Lo Iacono and Gross, 2008; Donaldson et al., 2014). 
We tested whether 5-HT neurons were functionally mature in early life (i.e., resemble adult 5-HT neurons) as changes during this period could represent a period of vulnerability to perturbation. Serotonin neuron active and passive membrane characteristics, neuron morphology, neuronal innervation, and 5-HT receptor-mediated responses were assessed. Recent electrophysiological studies in rats and mice indicate differences in 5-HT neuron characteristics between the median raphe (MR) and DR subfields, and also between the DR subfields; that is, lower activation threshold and higher stimulated spike frequency in lateral wing DR (lwDR) versus ventromedial DR (vmDR) neurons (Beck et al., 2004; Crawford et al., 2010; Calizo et al., 2011). Therefore, we recorded from neurons in the vmDR, lwDR, and MR. We show that during the first week of life (P4) 5-HT neurons, especially those in the vmDR and lwDR, have an undifferentiated or immature phenotype marked by increased excitability, limited excitatory and inhibitory inputs, absence of $5-\mathrm{HT}_{1 \mathrm{~A}}$ receptor-mediated responses, and highly branched and immature dendritic morphology. During the subsequent 2 weeks, neurons undergo physiological and morphological changes, becoming "adult-like."

\section{Materials and Methods}

Animals

Transgenic male mice expressing yellow fluorescent protein (YFP) driven by the 5 - $\mathrm{HT}$ neuron-specific Pet-1 promoter (Pet-1::YFP) or wild-type littermates were used to examine the postnatal development of 5-HT neurons in the DR and MR (Scott et al., 2005). This transgenic mouse line has been backcrossed at least 10 generations to the $\mathrm{C} 57 \mathrm{BL} / 6$ strain in our laboratory. All animals were used in accordance with the National Institutes of Health Guide for the Care and Use of Laboratory Animals, and all experiments were approved by the institutional animal care and use committee.

\section{Electrophysiology}

Slice preparation and recording. Animals were killed by decapitation at postnatal day 4 (P4) to P6, P11-P13 (P12), P20-P24 (P21), or in adulthood $(\mathrm{P} 60+)$. Brain slices were prepared as previously described (Crawford et al., 2010, 2011). After sectioning on a vibratome (Leica Microsystems), 200- $\mu$ m-thick coronal brain slices containing DR and MR were placed in artificial CSF (aCSF; in mM: $\mathrm{NaCl} \mathrm{124,} \mathrm{KCl} 2.5$, $\mathrm{NaH}_{2} \mathrm{PO}_{4} 1.25, \mathrm{MgSO}_{4} 2.0, \mathrm{CaCl}_{2} 2.5$, dextrose 10 , and $\mathrm{NaHCO}_{3} 26$ ) bubbled with $95 \% \mathrm{O}_{2} / 5 \% \mathrm{CO}_{2}$. Slices were maintained at $37^{\circ} \mathrm{C}$ for $1 \mathrm{~h}$ and then at room temperature until recording. L-tryptophan $(2.5 \mu \mathrm{M}$; Sigma-Aldrich) was included in the holding chamber to maintain 5-HT synthesis but was not present in aCSF during recording (Liu et al., 2005).

During recording, slices were placed in a recording chamber (Warner Instruments) and perfused at a rate of $\sim 2 \mathrm{ml} / \mathrm{min}$ with oxygenated $(95 \%$ $\mathrm{O}_{2} / 5 \% \mathrm{CO}_{2}$ ) aCSF heated to $32^{\circ} \mathrm{C}$ by an in-line heater (Warner Instruments). Neurons were visualized using a Nikon E600 upright microscope and targeted under differential interference contrast (DIC). Electrodes were filled with standard electrolytes (in mM; K-gluconate 130; $\mathrm{NaCl} 5$;
B

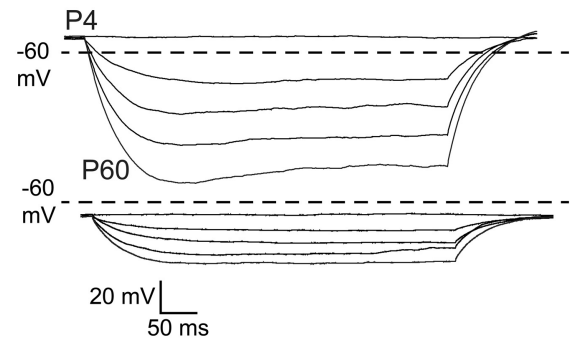

D

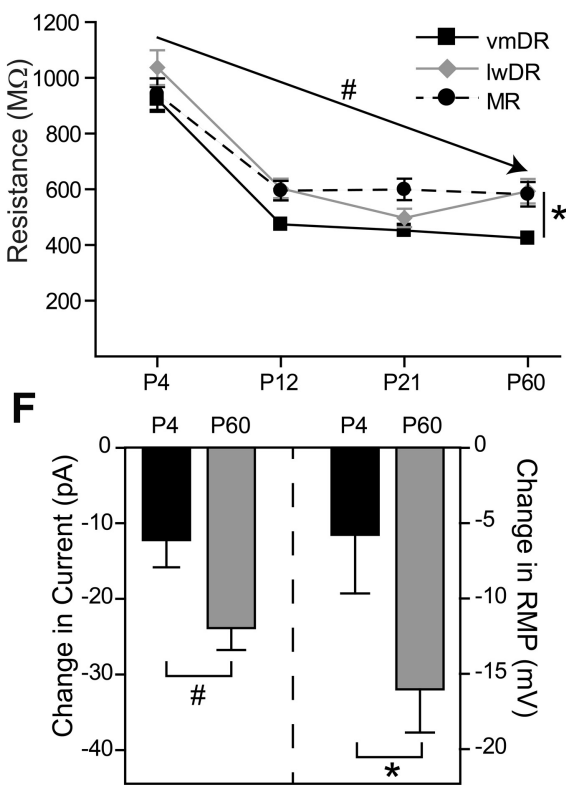

Figure 1. Membrane characteristics changed with age and differed across subfields. $A, D I C$ (top) and fluorescent (bottom) images of a Pet-1::YFP ${ }^{+}$serotonin cell that was chosen for recording. $\boldsymbol{B}$, Change in membrane potential in response to current injection ( -80 to 0 pA in 20 pA steps) from representative P4 and P60 vmDR 5-HT neurons. Scale is the same for both sets of traces, greater resistance than vmDR (subfield: $F_{(2,354)}=12.62, p<0.001 ;{ }^{*} \mathrm{MR}=\mathrm{IwDR}>\mathrm{vmDR}$ ). $\boldsymbol{E}$, $\boldsymbol{F}$, The $1 \mathrm{~mm} \mathrm{BaCl} 2$ induced a significantly larger inward current in P60 neurons than in P4 neurons ( $\# t=2.53, p=0.02$ ) as seen in representative traces; the scale is the same for both. In addition, barium induced a significantly larger depolarization at $\mathrm{P} 60\left({ }^{*} t=2.18, p=0.04\right)$.

Na phosphocreatine 10; $\mathrm{MgCl}_{2}$ 1; EGTA 0.02; HEPES 10; MgATP 2; and $\mathrm{Na}_{2}$ GTP 0.5 ; with biocytin $0.1 \%$; $\mathrm{pH} 7.3$ ) or high $\left[\mathrm{Cl}^{-}\right]$electrolyte for recording IPSCs (in mm; K-gluconate 75; $\mathrm{K}-\mathrm{Cl} 75 ; \mathrm{NaCl} 5$; Na phosphocreatine $10 ; \mathrm{MgCl}_{2} 1$; EGTA 0.02; HEPES 10; MgATP 2; and $\mathrm{Na}_{2} \mathrm{GTP} 0.5$; with biocytin $0.1 \%$; $\mathrm{pH} 7.3$ ). Whole-cell recordings were controlled using a Multiclamp 700B amplifier (Molecular Devices), and signals were collected and stored using a Digidata 1320 analog-to-digital converter and pClamp 9.0 or 10.0 software (Molecular Devices). Following recording, slices were stored in $4 \%$ paraformaldehyde at $4^{\circ} \mathrm{C}$ for further immunohistochemical processing. Chemicals for buffers and electrolytes were purchased from Sigma-Aldrich.

Characteristics. Passive and active membrane characteristics were recorded using current-clamp techniques as previously described (Beck et al., 2004; Crawford et al., 2010; Lemos et al., 2011). Membrane characteristics were obtained by administering $500 \mathrm{~ms}$ current injections in 20 $\mathrm{pA}$ steps from -80 to $160 \mathrm{pA}$. Action potential (AP) characteristics were recorded in current-clamp by administering enough current to elicit a single spike.

Postsynaptic activity and $5-H T_{1 A}$ and $5-H T_{1 B}$ responses. Using voltageclamp techniques, as previously described (Lemos et al., 2006; Crawford et al., 2011), baseline current was recorded for 3-5 $\mathrm{min}$, then the nonse- 

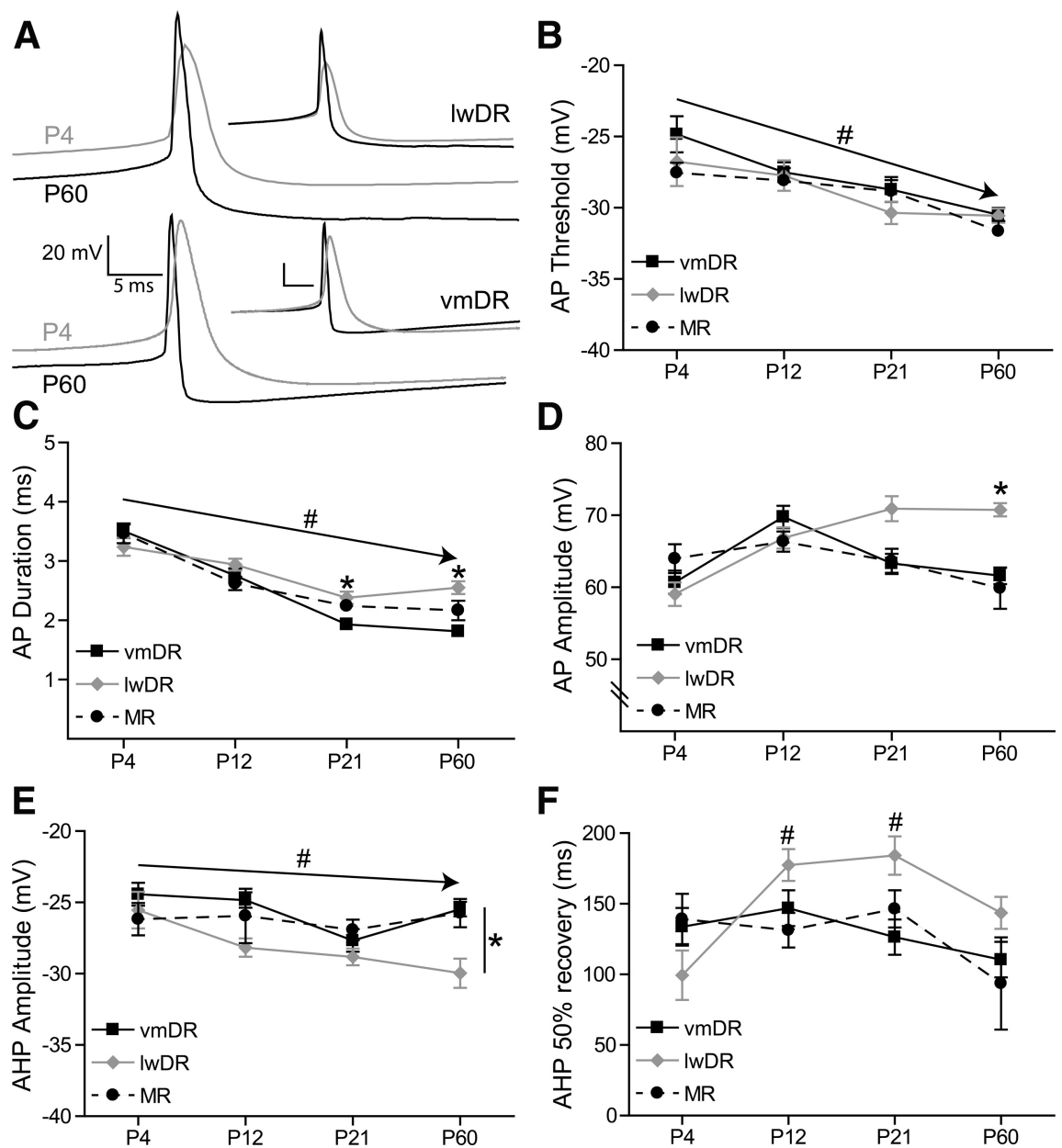

F

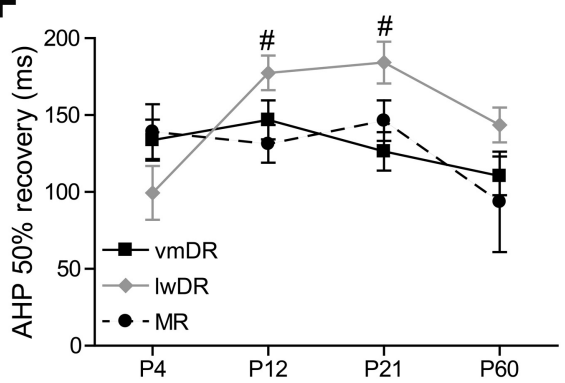

Figure 2. Action potential (AP) characteristics changed with age and differed slightly across subfields. $\boldsymbol{A}$, Representative current-evoked AP traces from P4 (light) and P60 (dark), IwDR (top), and vmDR (bottom) cells. Thresholds of scaled down traces were matched to better illustrate the changes in the shape of the AP at $P 4$ and $P 60$. Scales values are the same for both subfields; small and large scales have the same values. $\boldsymbol{B}$, AP threshold decreased with age in all subfields (age: $F_{(3,342)}=9.281, p<0.001$; $\# P 4>P 12>P 21=P 60) . C$, AP duration decreased across age in all subfields (age $\times$ subfield: $F_{(6,341)}=3.81, p=0.001 ; \# P 4>$ $P 12>P 21=P 60)$, with the largest change in the vmDR ( $\left.{ }^{*} \mid w D R \geq M R \geq v m D R\right) . D$, Amplitude increased in the lwDR (age $X$ subfield: $F_{(6,342)}=5.142, p<0.001$; ${ }^{\prime} \mid \mathrm{WDR}>$ vmDR $=$ MR at P60). $E$, AHP amplitude decreased across age (\#age: $F_{(3,341)}=$ $6.281, p=0.002$ ) and was largest in the IwDR ( ${ }^{*}$ subfield: $\left.F_{(2,341)}=2.786, p=0.041\right) . \boldsymbol{F}$, AHP duration, as measured by $50 \%$ recovery time from peak amplitude to baseline, increased across age only in the IwDR (age $\times$ subfield: $F_{(6,328)}=2.194, p=0.043$; $\# P 4=P 60<P 12=P 21$ in IwDR).

lective 5- $\mathrm{HT}_{1,7}$ agonist 5-carboxamidotryptamine (5-CT; 100 nм; Sigma-Aldrich) was added and the current was recorded until a steadystate outward potassium current was obtained (a total of $\sim 5 \mathrm{~min}$ ). This outward current has previously been characterized as being mediated by the $5-\mathrm{HT}_{1 \mathrm{~A}}$ receptor in the dorsal and median raphe (Beck et al., 2004). When recording EPSCs, a standard electrolyte was used and the $\mathrm{GABA}_{\mathrm{A}}$ receptor antagonist bicuculline ( $20 \mu \mathrm{M}$; Sigma-Aldrich) was added to the aCSF. When recording IPSCs, high $\left[\mathrm{Cl}^{-}\right]$electrolyte was used, and the AMPA/kainate receptor antagonist DNQX (20 $\mu$; Sigma-Aldrich) was added to the aCSF. High $\left[\mathrm{Cl}^{-}\right]$electrolyte reverses the ionic gradient for chloride altering the IPSC reversal potential to facilitate their measurement. In addition to the $5-\mathrm{HT}_{1 \mathrm{~A}}$-mediated change in baseline current, the $5-\mathrm{HT}_{1 \mathrm{~B}}$ receptor-mediated inhibition of EPSC and IPSC activity by $5-\mathrm{CT}$ administration was measured, as was previously characterized in the raphe (Lemos et al., 2006).

$5-H T_{1 A}$ receptor-effector mechanism. To test whether the receptoreffector mechanism was present for the $5-\mathrm{HT}_{1 \mathrm{~A}}$ receptor-mediated response, the receptor was bypassed by adding a nonhydrolyzable analog of GTP to the electrolyte (i.e., GTP $\gamma S$; 15 mm; Roche Diagnostics). After patching onto the neuron, the electrolyte diffuses into the neuron activating the G-protein (Okuhara and Beck, 1998). The current was re- corded using voltage-clamp techniques from the moment of breaking into the cell so that the outward current elicited by the GTP $\gamma \mathrm{S}$ activation of the G-protein could be recorded as it dialyzed into the cell and achieved steady-state levels.

Resting membrane potential mechanism. Membrane characteristics were acquired as described above in current-clamp before and following voltage-clamp recordings during which a potassium channel blocker was added. In voltage-clamp, a 2-3 min baseline recording was made, then $1 \mathrm{~mm} \mathrm{BaCl}_{2}$ ( $1 \mathrm{~mm}$; SigmaAldrich) was added to the perfusate. Current was recorded for 2-3 min beyond steady state ( 5-6 $\mathrm{min}$ ). To prevent precipitate formation, modified aCSF was used for this experiment: HEPES was increased to $10 \mathrm{~mm}$, and phosphate and bicarbonate were excluded (Cameron et al., 2000).

\section{Neuron morphology}

Histology and image acquisition. The morphology of recorded neurons was visualized by staining for biocytin as previously described (Calizo et al., 2011; Crawford et al., 2011). Slices were washed in $0.1 \mathrm{M}$ PBS ( $0.1 \mathrm{~m}$ sodium phosphate plus $0.9 \% \mathrm{NaCl}$ ) for $3 \times 10 \mathrm{~min}$, blocked in PBST-BSA (PBS with $0.5 \%$ Triton $\mathrm{X}-100$ and $0.04 \% \mathrm{BSA}$ ) for $30 \mathrm{~min}$, and then incubated in streptavidin-conjugated Alexa Fluor 647 (1:200; Invitrogen) in PBST-BSA for $90 \mathrm{~min}$ at room temperature. Then, after $3 \times$ 10 min washes in PBS, sections were mounted on Superfrost slides (Fisher Scientific) and coverslipped with Prolong Gold Anti-fade mounting media (Invitrogen) or Fluoromount-G (Electron Microscopy Sciences). Chemicals for buffers were purchased from Sigma-Aldrich. Using an Olympus FluoView FV1000 confocal microscope with FluoView FV10-ASW software (version 1.7; Olympus) and a $20 \times$ objective, an image stack was acquired with serial images taken every $0.5 \mu \mathrm{m}$ throughout the extent of the neuronal dendritic tree.

Morphology analysis. For each image stack neuronal somas were detected and 3-D tracing of processes was performed using Neurolucida (MicroBrightfield). Neurolucida was also used for statistical analyses of the number of primary branches, the number of nodes, the total dendritic length, as well as a Scholl analysis of processes.

\section{Immunostaining}

Tissue processing. Animals were deeply anesthetized then perfused transcardially with $0.9 \%$ saline followed by $4 \%$ paraformaldehyde in $0.1 \mathrm{~m}$ phosphate buffer. Brains were post-fixed in $4 \%$ paraformaldehyde for $2 \mathrm{~h}$ (GAD67 staining only) or overnight at $4^{\circ} \mathrm{C}$ and then submerged in $30 \%$ sucrose in $0.1 \mathrm{M}$ phosphate buffer. Coronal sections of the DR and MR were cut at $30-40 \mu \mathrm{m}$ on a cryostat and stored in cryprotectant at $-20^{\circ} \mathrm{C}$.

Immunohistochemistry. In general, sections were washed $3 \times 10 \mathrm{~min}$ in PBS, blocked with PBST-BSA for $30 \mathrm{~min}$, and then incubated in primary antibody in PBST-BSA overnight or longer. Subsequently, sections were rinsed with PBST-BSA $3 \times 10$ min followed by a $2 \mathrm{~h}$ incubation in fluorescently labeled secondary antibody. Finally, sections were rinsed $3 \times 10 \mathrm{~min}$ in PBS, mounted on Superfrost slides (Fisher Scientific), and coverslipped using Fluoromount-G medium (Electron Microscopy Sciences). Specific details and variations are provided below.

To determine whether GABA neurons were present in the DR at $\mathrm{P} 4$, as they are in adulthood, brain slices were incubated at $4^{\circ} \mathrm{C}$ for 3 nights 
using monoclonal antibody recognizing GAD67 (1:10,000; clone 1G10.2, Millipore) and rabbit anti-5-HT (this antibody was omitted if subject was $\mathrm{YFP}^{+} ; 1: 2000$; ImmunoStar) followed by a $4 \mathrm{~h}$ incubation in Alexa Fluor 647 donkey anti-mouse $\operatorname{IgG}_{2 \mathrm{a}}$ and Alexa Fluor 488 donkey anti-rabbit (1:250; Invitrogen). For GAD67 staining, buffers were made without Triton X-100 except for the 30 min blocking step.

To determine whether YFP-expressing cells were making 5-HT at different age points, we incubated brain slices in rabbit anti-5-HT in PBSTBSA (1:2000; ImmunoStar) at $4^{\circ} \mathrm{C}$ for 3 nights. After primary antibody incubation, sections were incubated in Alexa Fluor 647 donkey antirabbit in PBST-BSA (1:250; Invitrogen). In adult mice, 5-HT colocalizes with the vesicular glutamate transporter VGlut3 (Fremeau et al., 2002; Calizo et al., 2011). To determine whether this was the case early in development (P4), we incubated brain slices in guinea pig anti-VGlut3 (1:1000; Millipore) at $4^{\circ} \mathrm{C}$ for 3 nights, then in biotinylated goat antiguinea pig (1:250 in PBST-BSA; Vector Laboratories), and finally in Alexa Fluor 647 streptavidin (1:500; Invitrogen).

Image acquisition. Photomicrographs of immunohistochemical staining were obtained using an Olympus FluoView FV1000 confocal microscope with FluoView FV10-ASW software (version 1.7; Olympus) and a $20 \times$ objective. Image stacks were acquired with serial images taken every $1 \mu \mathrm{m}$ through the section. In ImageJ, image stacks were trimmed to 10 slices ( 3 slices for images of cells in Fig. 6A, i-iv) through the middle of the section and then smoothed. A $z$-projection using the Max Intensity method was then created for each channel. $z$-projections were adjusted for contrast and brightness in Photoshop (Adobe Systems) to minimize background. Overlays and colorization were performed in Photoshop.

\section{Immunohistochemistry quantification}

To determine the relative colocalization of Pet-1 promoter-driven YFP expression with 5-HT ( $n=4$ subjects), confocal image stacks and $z$-projections were acquired as described above. Stacks were obtained for a section through a midlevel section of the vmDR (bregma -4.48) and more caudal section containing the lwDR (bregma -4.72). Using layers in Photoshop, YFP and 5-HT cells were marked and counted independently. Then cells containing both YFP and 5HT were counted by observing both count layers at once. Similar procedures were used to quantify the level of colocalization between vGlut3-immunoreactive cells and YFP-expressing cells ( $n=3$ subjects).

For quantification of GAD67 cell number in the rostral (bregma -4.24), middle (bregma -4.48), and caudal (bregma -4.72) DR, confocal stacks of the DR were obtained from brains of both P4 $(n=6)$ and adult (P60, $n=6)$ mice. $z$-projections of image stacks were created in ImageJ (typically three to four per brain section) and reconstructed in Photoshop to create a panorama of the DR. Using layers in Photoshop, cells were marked and counted unilaterally. For analysis of GAD67immunoreactive fiber density in the vmDR, a $310.5 \times 310.5 \mu \mathrm{m}(500 \times$ 500 pixels) section centered over the midline and aligned to the upper edge of the vmDR (bregma -4.48) was cropped from the panoramas. Using ImageJ, the relative area covered by immunoreactivity was determined using gray-level thresholding. Threshold was defined as the mean gray level plus two times the SD of images from P4 mice. These values were obtained by averaging individual mean and SD from image histograms and adequately identified immunoreactivity versus background.

\section{Statistics}

Electrophysiological data were collected using Clampex (Molecular Devices) and analyzed using Clampfit (Molecular Devices) or Minianalysis (Synaptosoft). Statistical tests were performed using STATISTICA (StatSoft). Two-factor ANOVAs using age (P4, P12, P21, or adult) and subfield (vmDR, lwDR, or MR) as factors were used to analyze most of the data, with a few exceptions noted below. Changes in current and resting membrane potential (RMP) following barium treatment were analyzed with independent $t$ tests comparing $\mathrm{P} 4$ to $\mathrm{P} 60$. Excitability plots were analyzed separately for each subfield with two-factor repeated-measures ANOVAs using age as the between-groups factor and injected current as the repeated measure. The effect of GTP $\gamma S$ versus 5-CT was analyzed with a two-factor ANOVA using age and treatment as factors. Scholl analysis data were analyzed separately for each subfield with two-factor
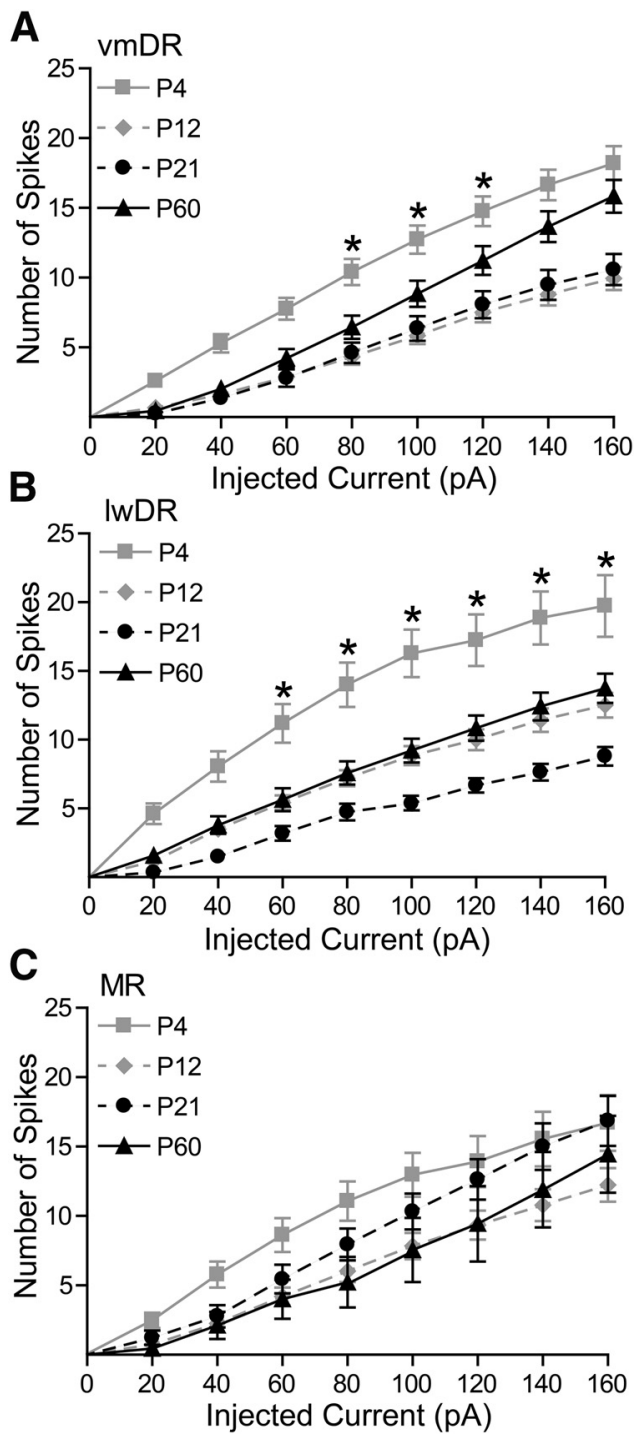

Figure 3. Excitability of vmDR and IwDR neurons was increased at P4. $\boldsymbol{A}-\boldsymbol{C}$, The excitability of 5 -HT cells decreased with age in the $\operatorname{vmDR}\left(\boldsymbol{A}\right.$; age $\times$ current: $\left.F_{(21,1036)}=10, p<0.001\right)$ and IwDR ( $\boldsymbol{B}$; age $\times$ current: $\left.F_{(21,616)}=5.9, p<0.001\right)$, but not the MR $(\boldsymbol{C})$. ${ }^{*}$ 4 4 had more action potentials than all other ages at indicated level of current injection.

repeated-measures ANOVAs using age as the between-groups factor and distance from center as the repeated measure. For GAD67 immunohistochemistry cell number analysis, data were analyzed using a repeatedmeasures ANOVA with age as the between-groups variable and region (rostral, middle, and caudal) as the repeated measure. GAD67 fiber immunoreactivity in the vmDR was analyzed using a $t$ test. Where appropriate, post hoc analyses were conducted using the Student-NewmanKeuls method. A probability level of $p<0.05$ was considered significant in all analyses.

\section{Results}

Intrinsic 5-HT membrane characteristics

The use of Pet-1::YFP mice facilitated the identification of 5-HT neurons before patching using DIC and fluorescent microscopy (Fig. 1A). Active and passive membrane characteristics data were derived from 366 recorded cells from the vmDR $(n=37,48,32,44), \operatorname{lwDR}(21,35,29,19)$, and MR $(31,37,24$, 9) of mice at ages P4, P12, P21, and P60, respectively. Membrane characteristics of DR and MR 5-HT neurons, especially in the vmDR and lwDR, had an immature phenotype at P4, but 


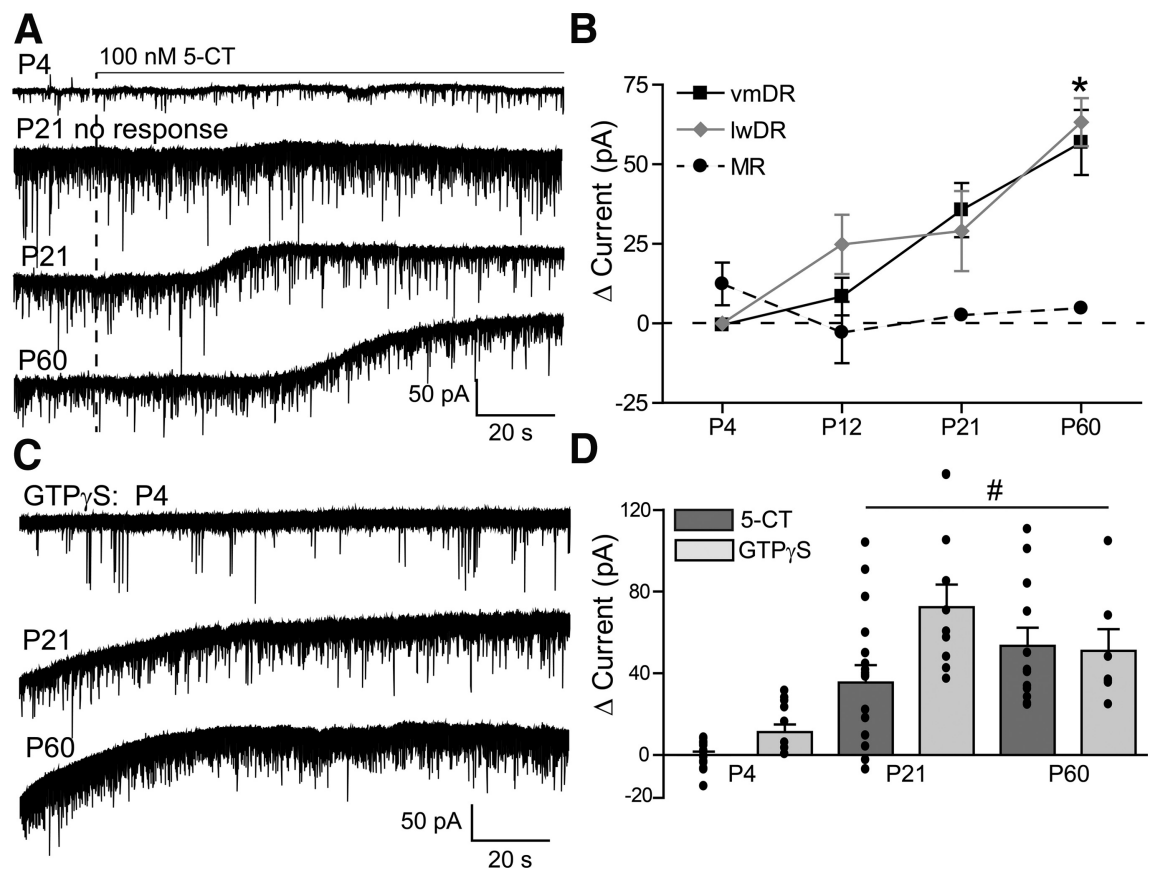

Figure 4. The 5- $-\mathrm{H}_{1 \mathrm{~A}}$ auto-receptor response was absent at $\mathrm{P} 4$. The $5-\mathrm{HT}_{1 \mathrm{~A}}$ auto-receptor response was absent at $\mathrm{P} 4$ and did not develop fully in the vmDR and IwDR until adulthood, although the effector (i.e., G-protein-coupled inward rectifying potassium channel) response appeared to be intact at P21. A, Representative traces showing the response to 5 -CT from vmDR 5-HT cells at P4, P21 (responsive and nonresponsive), and P60. The scale is the same for all traces, and the dotted line indicates addition of $100 \mathrm{~nm}$ 5-CT. $B$, The development of the $5-\mathrm{HT}_{1 \mathrm{~A}}$ autoreceptor-mediated outward current was different across subfields (age $X$ subfield: $\left.F_{(6,125)}=4.99, p<0.001\right)$. No outward current in response to 5 -CT was observed at P4, and P12 and P21 did not differ significantly from P4. At P60, 5-CT induced a marked outward current in the vmDR and IwDR, but not the MR (*vmDR = IwDR $>$ MR). $C$, Representative traces showing the response to GTP $\gamma 5$ from vmDR 5-HT cells at P4, P21, and P60. The scale is the same for all traces. $D$, Summary graph of data from neurons recorded with GTP $\gamma S$, which constitutively activates G-proteins. At P4, there was no response to GTP $\gamma$ S, but at P21 there was an adult-like response (\#age: $F_{(2,67)}=27.00, p<0.001$; \#P4 $<$ P21 $=$ P60). Dot plots are provided to illustrate the absence of response to 5 -CT of some cells at P21. All cells tested responded to GTP $\gamma S$ at P21. The interaction between age and treatment just missed significance (age $\times$ treatment: $F_{(2,67)}=3.09, p=0.052$ ), but there was a main effect of treatment $\left(F_{(1,67)}=6.00, p=0.021 ; \mathrm{GTP} \gamma \mathrm{S}>5-\mathrm{CT}\right)$.

developed mature adult-like characteristics by P21. Representative raw data traces of the membrane potential response to current injection recorded in a P4 and P60 neuron are shown in Figure $1 B$. Resting membrane potential was significantly depolarized in 5-HT neurons in the vmDR and lwDR at P4 compared with P12, P21, and P60 (Fig. 1C). In contrast, the RMP did not change across age in 5-HT neurons of the MR (age $\times$ subfield: $\left.F_{(6,354)}=3.44, p=0.003\right)$. As can be seen in the traces, membrane resistance was significantly greater at $\mathrm{P} 4$ than at P12, P21, or P60 neurons in all subfields (Fig. 1D; age: $\left.F_{(3,354)}=93.34, p<0.001\right)$. Collapsed across age, the vmDR had a lower resistance than the lwDR and MR (subfield: $F_{(2,354)}=12.62$, $p<0.001)$. The hyperpolarization of the RMP coupled with the decrease in resistance (i.e., increase in conductance) in the vmDR and lwDR implicates the activation of ion channels during this postnatal period of development.

\section{Possible mechanism for decrease in \\ RMP}

Potassium leak currents mediated through two-pore domain channels $\left(\mathrm{K}_{2 \mathrm{P}}\right)$ are thought to modulate resting membrane potential (Talley et al., 2003). In the DR, TREK-1, Task-1, and Task-3 $\mathrm{K}_{2 \mathrm{P}}$ channels have been found in 5-HT neurons, and in TREK-1 knock-out mice the firing rate of raphe neurons is increased (Washburn et al., 2002; Heurteaux et al., 2006). To determine whether a potassium leak current might be involved in the devel- opmental change in RMP, potassium channels were blocked with $\mathrm{Ba}^{2+}$ while recording from $\mathrm{P} 4(n=8)$ or $\mathrm{P} 60(n=10)$ vmDR 5-HT neurons. P60 neurons responded to $\mathrm{Ba}^{2+}$ with a larger inward current than neurons at P4 (Fig. $1 E, F$; $t=$ 2.53, $p=0.02$ ). In addition, there was a larger depolarization of the RMP in response to $\mathrm{Ba}^{2+}$ administration in P60 neurons compared with P4 neurons (Fig. $1 F ; t=2.18, p=0.04$ ). Together, these data suggested the presence of a potassium current that is present in the adult neurons in the basal state.

\section{Action potential characteristics}

One of the primary characteristics of 5-HT neurons is the shape of the AP, known to have a long duration and large afterhyperpolarization (AHP; Vandermaelen and Aghajanian, 1983). During development, there were major changes in the shape of the AP, as represented by the raw data traces from lwDR and vmDR neurons shown in Figure $2 A$. These traces illustrate the hyperpolarization of the threshold, shortening of the AP duration, and increase in AP amplitude (inset matches threshold to show the change in duration and amplitude more clearly). The AP threshold became more hyperpolarized with age across all subfields (Fig. $2 B$; age: $F_{(3,342)}$ $=9.281, p<0.001)$. The AP duration decreased across ages from $4 \mathrm{~ms}$ to the characteristic adult duration of $2 \mathrm{~ms}$ in all subfields (Fig. 2C; age $\times$ subfield: $\left.F_{(6,341)}=3.81, p=0.001\right)$ with the largest change in the vmDR. AP amplitude did not change in the MR, but increased transiently in the vmDR at P12. The amplitude increase was most obvious in the lwDR (Fig. $2 D$; age $\times$ subfield: $F_{(6,342)}=$ 5.142, $p<0.001$ ), but was only statistically different from other subfields at P60. The AHP amplitude was larger in the lwDR than the vmDR or MR, and significantly increased in amplitude across age in all subfields (Fig. $2 E$; age: $F_{(3,341)}=$ 6.281, $p=0.002$; subfield: $\left.F_{(2,341)}=2.786, p=0.041\right)$. The time course of the AHP only changed in the lwDR where the $50 \%$ recovery time (i.e., the duration of the AHP) increased with age (Fig. $2 F$; age $X$ subfield: $F_{(6,328)}=2.194, p=0.043$ ).

\section{Frequency-intensity plots and activation gap}

The excitability of the P4 neurons in the lwDR and vmDR subfields was greater than at other ages. Analysis of the number of APs elicited by depolarizing current injection indicated that 5 -HT neurons in the vmDR (Fig. $3 A$; age $\times$ current: $F_{(21,1036)}=$ $10, p<0.001$ ) and lwDR (Fig. $3 B$; age $\times$ current: $F_{(21,616)}=5.9$, $p<0.001$ ), but not the MR (Fig. 3C), were more sensitive to current injection (i.e., increased firing rate) at $\mathrm{P} 4$ than at other ages. These results mirror those of membrane resistance and RMP.

All of these changes in the active membrane properties of the 5-HT neurons are probably attributable to the development of sodium, potassium, and calcium channels that underlie the AP 
and AHP shapes. As with the changes in the passive membrane properties, the greatest alterations were seen in the lwDR and vmDR subfields.

\section{Activation of 5- $\mathrm{HT}_{1 \mathrm{~A}}$ autoreceptor}

Another primary characteristic of 5-HT neurons is the $5-\mathrm{HT}_{1 \mathrm{~A}}$ autoreceptormediated response that was surprisingly absent in cells recorded from young pups. Normally, in adult P60 5-HT neurons, addition of the nonselective $5-\mathrm{HT}_{1,7}$ agonist 5-CT activates the G-protein-coupled $5-\mathrm{HT}_{1 \mathrm{~A}}$ autoreceptor eliciting an outward current via a G-protein-coupled inwardly rectifying potassium channel (GIRK), as depicted in the raw data trace in the bottom of Figure 4A (Andrade et al., 1986; Andrade and Nicoll, 1987; Beck et al., 2004; Marinelli et al., 2004). At P4, 5-CT did not induce an outward current in any subfield (Fig. 4A, top trace). At P12 and P21 in the vmDR and lwDR, there appeared to be a small increase in response to 5-CT, but only at P60 was the magnitude of the response significantly greater than at $\mathrm{P} 4$ (Fig. $4 B$; age $\times$ subfield: $F_{(6,125)}$ $=4.99, p<0.001)$. There was no increase in the response to 5 -CT across age in the MR.

It is possible that 5 -HT neurons were less sensitive to 5-CT and required a higher concentration to elicit a response. Therefore, we examined the effects of higher concentrations of 5-CT on P4 vmDR 5-HT neurons $(N=2)$. The cells recorded showed no or minimal response to 100 nм 5-CT $(-1.1$ and $6.2 \mathrm{pA}$ current change from baseline). This was consistent with our larger dataset. Increasing the concentration to $500 \mathrm{~nm}$ or $1 \mu \mathrm{M}$ did not induce a response. Compared with baseline current levels, the magnitude of the responses was $-7.2 /-7.8 \mathrm{pA}$ and $2.3 /-0.2 \mathrm{pA}$, respectively at $500 \mathrm{~nm} / 1 \mu \mathrm{M}$ concentrations. These data suggested that the lack of response was not due merely to inadequate concentration.

A more likely explanation is that the lack of or muted response to $5-\mathrm{HT}_{1 \mathrm{~A}}$ receptor activation in the neurons recorded from $\mathrm{P} 4$ to P21 pups was due to the absence of the effector system (i.e., G-protein and/or GIRK). To test this, we recorded from vmDR neurons with electrolyte-containing GTP $\gamma \mathrm{S}$, the nonhydrolyzable analog of GTP, to constitutively activate G-proteins. If both $\mathrm{G}_{\mathrm{i} / \mathrm{o}}$ and GIRK proteins were present, this should elicit an outward current. Strong outward currents were observed in all vmDR neurons recorded at $\mathrm{P} 21$ or $\mathrm{P} 60$, but not at $\mathrm{P} 4$ (Fig. 4C,D). When GTP $\gamma S$ data were compared with 5-CT data, we found that GTP $\gamma S$ induced an adult-like response at P21 and P60, but not at P4 (Fig. $4 C$; age: $F_{(2,67)}=27.00, p<0.001$ ). This indicated that the effector system, G-protein, and/or GIRK, were not present at $\mathrm{P} 4$, but were present and could be activated at P21. There was also an effect of treatment with GTP $\gamma S$ inducing an overall larger response than 5-CT (treatment: $F_{(1,67)}=6.00, p=0.021$. This appeared to be driven primarily by the P21 time point, although the interaction just missed significance (age $\times$ treatment: $F_{(2,67)}=3.09$, $p=0.052)$. The marginally lower 5 -CT response at $\mathrm{P} 21$ is due to the fact that some of the cells did not respond at P21 (Fig. 4A). It is possible that these cells are not yet expressing the $5-\mathrm{HT}_{1 \mathrm{~A}}$ recep-
B
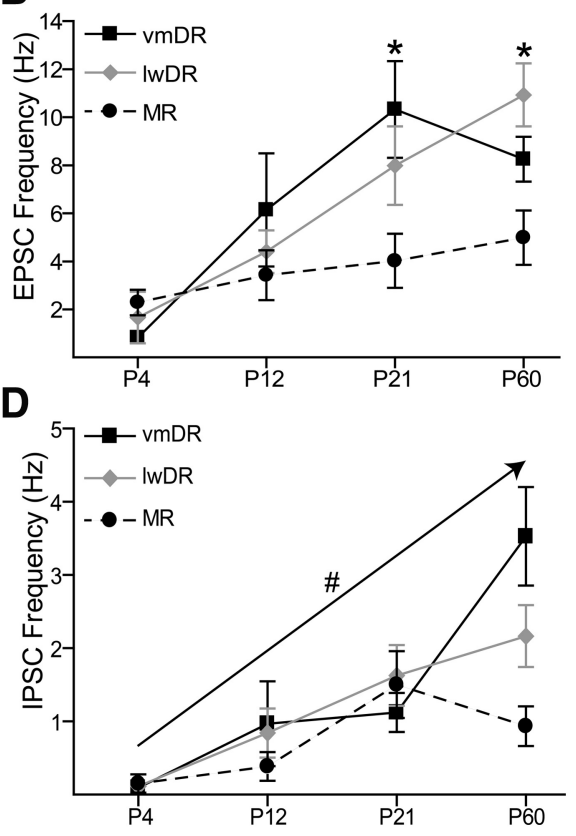

Figure 5. Excitatory glutamatergic and inhibitory GABAergic postsynaptic current (PSC) activity increased with age, but differed was present in only $39 \%$ of cells recorded at $\mathrm{P} 4$ (all subfields combined), but IPSC frequency increased with age (\#age: $F_{(3,117)}=$ statistically significant subfield differences.

tor or that the effector system, which appears to be present and functional at P21, is not coupled to the receptor. At P60, the magnitudes of the responses elicited by receptor activation using 5 -CT and by GTP $\gamma \mathrm{S}$ were comparable, suggesting that the receptor-effector coupling was intact. These data are novel and provide essential information that the effector system is unavailable and cannot be activated at $\mathrm{P} 4$. In addition, even though the effector system was available at P21, 5 of 17 5-HT neurons (i.e., 30\%) did not exhibit a $5-\mathrm{HT}_{1 \mathrm{~A}}$-mediated outward current. This receptor-effector system clearly was developing within the first 2 weeks of life, providing a target for interference by environmental factors.

\section{Excitatory and inhibitory innervation}

Glutamatergic EPSC activity was measured in the presence of bicuculline to block any inhibitory GABAergic IPSC activity that might be present. Traces recorded from vmDR showing EPSC activity at the different ages are shown in Figure 5A. At $\mathrm{P} 4$, all 5-HT neurons recorded had minimal functional glutamatergic innervation as measured by baseline EPSC activity (Fig. 5A). The frequency of EPSCs increased across age in the vmDR and lwDR, but the small increase in the MR was not significant (Fig. $5 B$; age $\times$ subfield: $F_{(6,116)}=2.678, p=$ $0.0180)$. Generally, the change in frequency was not accompanied by major changes in the amplitude or kinetics of the EPSCs, although some minor differences were noted (summarized in Table 1). An increase in EPSC amplitude and charge (area of the averaged EPSC) over age was observed only in the lwDR (age $\times$ subfield: amplitude, $F_{(6,116)}=2.70, p=0.017$; charge, $\left.F_{(6,116)}=2.74, p=0.016\right)$. As expected from the data shown above, phasic current (frequency $\times$ charge) also differed between ages and subfields, and reflected the significant 
Table 1. Characteristics of glutamatergic EPSC activity in subfields of the raphe during development

\begin{tabular}{|c|c|c|c|c|c|c|}
\hline Age $(n)$ & $\begin{array}{l}\text { Frequency } \\
(\mathrm{Hz})^{a}\end{array}$ & $\begin{array}{l}\text { Amplitude } \\
(\mathrm{pA})^{b}\end{array}$ & Rise (ms) & $\begin{array}{l}\text { Decay } \\
(\mathrm{ms})^{d}\end{array}$ & $\begin{array}{l}\text { Charge } \\
(\mathrm{pA} / \text { peak })^{b}\end{array}$ & $\begin{array}{l}\text { Phasic current } \\
(\mathrm{pA} / \mathrm{s})^{e}\end{array}$ \\
\hline \multicolumn{7}{|l|}{ vmDR } \\
\hline P4 (12) & $0.8 \pm 0.2$ & $23.3 \pm 2.7$ & $1.6 \pm 0.1$ & $1.8 \pm 0.2$ & $52.3 \pm 7.3$ & $48.6 \pm 13.7$ \\
\hline P21 (10) & $10.3 \pm 2.0$ & $23.2 \pm 4.4$ & $1.8 \pm 0.2$ & $2.1 \pm 0.3$ & $50.9 \pm 5.6$ & $585.3 \pm 182.4$ \\
\hline $\mathrm{P} 60$ (10) & $8.3 \pm 0.9$ & $24.5 \pm 2.0$ & $1.8 \pm 0.1$ & $1.6 \pm 0.2$ & $62.9 \pm 3.4$ & $532.6 \pm 81.9$ \\
\hline \multicolumn{7}{|l|}{ IwDR } \\
\hline P21 (13) & $8.0 \pm 1.6$ & $16.2 \pm 0.8$ & $1.7 \pm 0.1$ & $2.1 \pm 0.1$ & $40.3 \pm 2.4$ & $328.9 \pm 80.6$ \\
\hline P60 (13) & $10.9 \pm 1.3$ & $28.9 \pm 1.6$ & $1.8 \pm 0.1$ & $1.4 \pm 0.2$ & $66.5 \pm 4.1$ & $734.2 \pm 98.1$ \\
\hline \multicolumn{7}{|l|}{ MR } \\
\hline P4 (17) & $2.3 \pm 0.5$ & $22.7 \pm 2.1$ & $1.8 \pm 0.1$ & $1.6 \pm 0.1$ & $41.7 \pm 4.9$ & $25.2 \pm 6.7$ \\
\hline P12 (10) & $3.4 \pm 1.0$ & $26.8 \pm 2.6$ & $1.6 \pm 0.1$ & $1.2 \pm 0.1$ & $56.4 \pm 10.8$ & $133.0 \pm 36.6$ \\
\hline P21 (6) & $4.0 \pm 1.1$ & $14.5 \pm 1.5$ & $2.0 \pm 0.2$ & $1.7 \pm 0.2$ & $27.3 \pm 1.9$ & $106.9 \pm 28.6$ \\
\hline
\end{tabular}

${ }^{a}$ Age $\times$ subfield: $F_{(6,116)}=2.678, p=0.0180$ (see Fig. $5 B$ ).

${ }^{b}$ Age $\times$ subfield: amplitude $F_{(6,116)}=2.70, p=0.017 ;$ charge: $F_{(6,116)}=2.74, p=0.016 ; \mathrm{P} 4=\mathrm{P} 12=\mathrm{P} 21<\mathrm{P} 60$ in IwDR for both amplitude and charge.

'Age: $F_{(3,116)}=2.98, p=0.034 ; \mathrm{P} 60>\mathrm{P} 12$.

${ }^{d}$ Age: $F_{(3,116)}=5.333, p=0.002 ; P 4=P 12<P 21>P 60$. Subfield: $F_{(2,116)}=5.996, p=0.003 ; \mathrm{vmDR}=\operatorname{lwDR}>$ MR.

${ }^{e}$ Age $\times$ subfield: $F_{(6,116)}=3.53, p=0.003 ; P 60>P 4$ in IwDR and vmDR, but not MR.

Table 2. Characteristics of GABAergic IPSC activity in subfields of the raphe during development

\begin{tabular}{|c|c|c|c|c|c|c|c|}
\hline Age $\left(n_{1} / n_{2}\right)$ & $\begin{array}{l}\text { Frequency } \\
(\mathrm{Hz})^{a}\end{array}$ & $\begin{array}{l}\text { Amplitude } \\
\text { (pA) }\end{array}$ & Rise $(\mathrm{ms})^{b}$ & $\begin{array}{l}\text { Decay } 1 \\
(m s)^{c}\end{array}$ & Decay 2 (ms) & $\begin{array}{l}\text { Charge } \\
(\mathrm{pA} / \text { peak })^{d}\end{array}$ & Phasic (pA/s) \\
\hline \multicolumn{8}{|l|}{ vmDR } \\
\hline P4 (6/2) & $0.1 \pm 0.1$ & $18.2 \pm 4.8$ & $1.6 \pm 0.1$ & $5.0 \pm 2.4$ & $46.8 \pm 33.4$ & $191.8 \pm 127.2$ & $69.0 \pm 58.6$ \\
\hline P21 (14/12) & $1.1 \pm 0.3$ & $26.1 \pm 1.6$ & $1.9 \pm 0.1$ & $4.7 \pm 0.3$ & $33.8 \pm 5.7$ & $250.4 \pm 16.2$ & $340.7 \pm 86.1$ \\
\hline P60 (8/8) & $3.5 \pm 0.7$ & $35.7 \pm 5.7$ & $1.9 \pm 0.1$ & $3.1 \pm 0.5$ & $20.3 \pm 9.0$ & $201.7 \pm 26.5$ & $768.8 \pm 229.0$ \\
\hline \multicolumn{8}{|l|}{ IwDR } \\
\hline P21 (12/11) & $1.6 \pm 0.4$ & $29.2 \pm 3.5$ & $2.0 \pm 0.1$ & $4.1 \pm 0.4$ & $29.7 \pm 13.3$ & $249.1 \pm 28.1$ & $430.1 \pm 107.4$ \\
\hline P60 (14/14) & $2.2 \pm 0.4$ & $29.0 \pm 3.1$ & $2.0 \pm 0.1$ & $3.3 \pm 0.3$ & $23.2 \pm 7.7$ & $186.7 \pm 14.5$ & $409.6 \pm 96.1$ \\
\hline \multicolumn{8}{|l|}{ MR } \\
\hline P4 (7/2) & $0.2 \pm 0.1$ & $25.6 \pm 11.6$ & $3.3 \pm 0.1$ & $7.1 \pm 4.5$ & $57.0 \pm 9.3$ & $576.9 \pm 398.1$ & $444.2 \pm 411.8$ \\
\hline P12 (14/10) & $0.4 \pm 0.2$ & $32.2 \pm 8.4$ & $2.4 \pm 0.2$ & $8.9 \pm 2.0$ & $47.8 \pm 9.9$ & $515.0 \pm 151.1$ & $223.6 \pm 88.3$ \\
\hline P21 (13/13) & $1.5 \pm 0.5$ & $28.8 \pm 3.2$ & $2.0 \pm 0.1$ & $4.5 \pm 0.5$ & $30.8 \pm 8.1$ & $323.3 \pm 68.9$ & $741.2 \pm 448.8$ \\
\hline
\end{tabular}

Not all cells had measureable IPSC activity. Frequency data was analyzed using all cells recorded $\left(n_{1}\right)$. All other characteristics were analyzed only for cells with IPSC activity ( $\left.n_{2}\right)$, although P4 was excluded from statistical analysis due to low $n_{2}$.

${ }^{a}$ Age: $F_{(3,117)}=9.68, p<0.001 ; \mathrm{P} 4 \leq \mathrm{P} 12 \leq \mathrm{P} 21<\mathrm{P} 60$.

${ }^{b}$ Age: $F_{(2,87)}=7.655, p=0.001 ; \mathrm{P} 12>\mathrm{P} 21=\mathrm{P} 60$.

'Age: $F_{(2,87)}=12.71, p<0.001 ; P 12>P 21=P 60$. Subfield: $F_{(2,87)}=3.87, p=0.025 ; M R>v m D R=I w D R$.

${ }^{d}$ Age: $F_{(2,87)}=5.341, p=0.006 ; \mathrm{P} 12>\mathrm{P} 21=\mathrm{P} 60$.

increases in EPSC frequency seen in the vmDR and lwDR, but not in the MR (age $\times$ subfield: $F_{(6,116)}=3.53, p=0.003$ ).

In contrast, GABAergic IPSC activity presented a different picture (Fig. 5C). Surprisingly, there was almost no IPSC activity at P4 in any subfield within the raphe; only $39 \%$ of cells had measurable IPSCs at P4, and most of these had a frequency $<0.3$ Hz. The percentage of cells with measurable IPSC activity increased to $77 \%$ at $\mathrm{P} 12,92 \%$ at $\mathrm{p} 21$, and $100 \%$ at $\mathrm{P} 60$, and the overall frequency of IPSCs increased with age as well (Fig. 5D; age: $\left.F_{(3,117)}=9.679, p<0.001\right)$. However, even though there was measurable IPSC activity at P12 and P21, the frequency of the events was low compared with the IPSC activity measured in the adult mice (age: $F_{(3,117)}=9.679, p<0.001$ ). Although there appeared to be a subfield difference, the statistical interaction was only approaching significance (age $\times$ subfield: $F_{(6,117)}=1.911$, $p=0.085)$. Because of the low number of P4 cells with IPSCs, only data from P12, P21, and P60 animals were used to analyze IPSC characteristics (summarized in Table 2). The mean rise time (age: $F_{(2,87)}=7.655, p=0.001$ ) and first decay exponential (age: $\left.F_{(4,87)}=12.71, p<0.001\right)$ decreased between P12 and P60. In concert with these changes, the average charge per peak was higher at $\mathrm{P} 12$ than at $\mathrm{P} 21$ or $\mathrm{P} 60$ (age: $F_{(2,87)}=5.341, p=0.006$ ), but the overall phasic current did not change.

Because of the extremely low IPSC activity in P4 neurons, we hypothesized that GABA neurons or GABA innervation might not yet be present in the DR at P4 to form local circuit connections. Immunohistochemistry for the GABA neuron marker GAD67 was used to examine the GABA system of P4 and P60 mice. In a qualitative comparison, several key differences were noted. Both P4 and adult animals had a cluster of GAD67 immunoreactivity (IR) neurons close to the midline in rostral coronal sections (Fig. 6A), but P4 subjects appeared to have fewer 
GAD67-IR neurons in more lateral and caudal regions of the adult DR. A quantitative analysis comparing rostral (bregma -4.24 ), middle (bregma -4.48), and caudal (bregma -4.72 ) sections of the DR in $\mathrm{P} 4$ and P60 mice ( $n=6$ per age) revealed that adults had more GAD67 ${ }^{+}$neurons than P4 pups in caudal sections of the DR, but groups did not differ in the rostral or middle DR (P4: $30.8 \pm 4.5,19.1 \pm 2.3$, and $9.7 \pm 1.5 ; \mathrm{P} 60: 31.5 \pm 2.2,28.2 \pm 4.6$, and $33.3 \pm 5.6$ for rostral, middle, and caudal sections, respectively; age $\times$ region: $\left.F_{(2,30)}=4.57, p=0.018\right)$. In adults, a distinct fiber plexus was observed at the midline within the vmDR in rostral and middle sections (Fig. 6A,B). Gray level thresholding of fibers in the vmDR between P4 and P60 animals indicated a higher density of immunoreactive puncta in adult animals $(22.7 \%$ of the area covered in adults; and $6.1 \%$ of the area covered in P4 pups; $n=6$ per age, $t=-3.04$, $p=0.012$ ). In more lateral and caudal regions of the adult raphe, there were very dense terminal fields (Fig. 6C). These apparent terminal fields were present in $\mathrm{P} 4$ animals, but appeared less densely stained (Fig. 6C). There were clear differences in GAD67-IR innervation and in the extent of GAD67-IR cell body distribution in the dorsal raphe of $\mathrm{P} 4$ and $\mathrm{P} 60$ mice, indicating that the GABA system of the dorsal raphe was not fully developed at P4 (Fig. $6 A)$. One intriguing feature of the GAD67-IR from the P4 brains, but not adult brains, was the collection of fibrous clusters located throughout the region that were later occupied by dense clusters of cells and terminals within and just dorsal to the tracts of the medial lateral fasciculus (Fig. 6A). These fiber clusters are most likely developing fiber tracts and could indicate developmental changes in the distribution of GAD67 within cellular processes. These results, to the best of our knowledge, are the first report of the surprising lack of GABAergic innervation and synaptic activity during development in the raphe.

\section{$5-\mathrm{HT}_{1 \mathrm{~B}}$ responses}

Another 5-HT receptor present in the raphe is the $5-\mathrm{HT}_{1 \mathrm{~B}}$ receptor located presynaptically, where it regulates glutamate and GABA release (Lemos et al., 2006). We compared the frequency of EPSCs and IPSCs before and after the administration of 5-CT to determine the influence of the $5-\mathrm{HT}_{1 \mathrm{~B}}$ receptor across development (Table 3 ). In response to $5-\mathrm{HT}_{1 \mathrm{~B}}$ receptor activation, the EPSC frequency decreased following 5 -CT administration in all subfields, but not at all ages. At P4, there was no decrease in EPSC frequency in any of the subfields. In the vmDR, EPSC frequency decreased following longitudinal fasciculus.
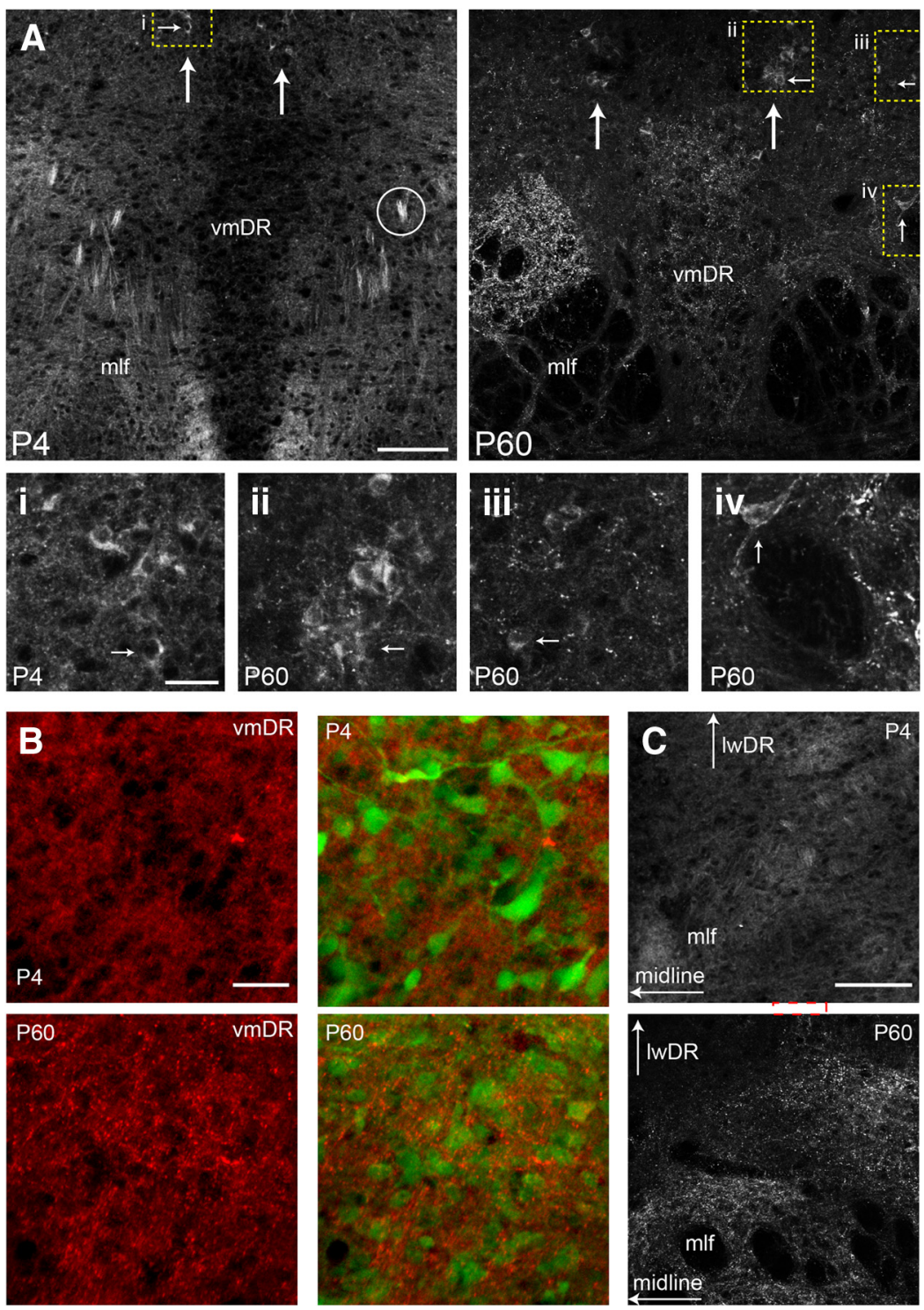

Figure 6. GAD67-IR throughout the DR was limited at P4 in contrast to adults. $A, G A D 67-I R$ in the rostral vmDR is shown for a P4 and P60 male mouse (top panels). Animals at both ages have a small cluster of neurons adjacent to 5 -HT cells near the midline (large arrows) and more scattered neurons laterally. The circle highlights unique staining patterns in the $\mathrm{P} 4$ that do not resemble cells or terminals but may indicate a developing fiber tract. Higher-magnification images are provided in the bottom panel (i-iv) to better illustrate GAD67-IR cells. Each image in the bottom panel corresponds to a yellow box in the top panel (corresponding roman numerals). Small arrows are used to indicate the same cell in both images for orienting purposes. Scale bars: top panels, 100 $\mu \mathrm{m}$; bottom panels, $25 \mu \mathrm{m}$. B, A magnification of the vmDR from a P4 and P60 mouse are shown to illustrate the differences in GAD67-IR puncta. Left panels show GAD67 staining alone, and right panels show GAD67 (red) merged with YFP (green). P4 mice lacked the punctate staining seen throughout the vmDR of the adult. Scale bar, $50 \mu \mathrm{m}$. C, GAD67-IR in the caudal lateral DR is shown for P4 and P60 mice. P4 animals lack the dense punctate staining seen in the adults. Scale bar, $100 \mu \mathrm{m}$. mlf, Medial

5-CT at P12 and P21 (age $\times$ treatment: $F_{(3,38)}=19.7, p=$ $0.017)$, but the difference just missed significance in adulthood $(p=0.055)$. In response to 5 -CT, EPSC frequency decreased at p12, p21, and p60 in the lwDR (age $\times$ treatment: $F_{(3,38)}=8.8, p<$ 0.001). In the MR, there was an overall decrease in EPSCs in response to 5 -CT, but there was no significant interaction with age (treatment: $F_{(1,41)}=20.05, p<0.001$ ).

The development of the $5-\mathrm{HT}_{1 \mathrm{~B}}$-mediated decrease in IPSC frequency was not quite as robust. There was an overall significant decrease in IPSCs in the $\operatorname{vmDR}\left(F_{(1,39)}=5.171, p=0.029\right)$ and $\operatorname{lwDR}\left(F_{(1,42)}=13.84, p=0.001\right)$ in response to 5 -CT, but there was no effect of treatment in the MR. 
Table 3. EPSC and IPSC frequency before and after 5-CT administration (i.e. 5 - $\mathrm{HT}_{1 \mathrm{~B}}$ response)

\begin{tabular}{|c|c|c|c|c|}
\hline & P4 & P12 & P21 & $P 60$ \\
\hline \multicolumn{5}{|l|}{ EPSC } \\
\hline \multicolumn{5}{|l|}{ vmDR } \\
\hline Baseline & (14) $0.87 \pm 0.17$ & (8) $9.67 \pm 3.34$ & (10) $12.23 \pm 2.84$ & (10) $8.25 \pm 0.93$ \\
\hline $5-\mathrm{CT}$ & (14) $0.77 \pm 0.18$ & (8) $5.07 \pm 2.01^{a}$ & (10) $9.01 \pm 2.18^{a}$ & (10) $6.25 \pm 0.66^{b}$ \\
\hline \multicolumn{5}{|l|}{ IwDR } \\
\hline Baseline & (8) $1.38 \pm 0.81$ & (9) $4.40 \pm 0.88$ & (12) $7.78 \pm 1.76$ & (13) $10.93 \pm 1.31$ \\
\hline 5-СТ & (8) $1.49 \pm 0.77$ & (9) $2.67 \pm 0.70^{a}$ & (12) $4.91 \pm 1.44^{a}$ & (13) $6.78 \pm 0.93^{a}$ \\
\hline \multicolumn{5}{|l|}{ MR } \\
\hline Baseline & (16) $2.20 \pm 0.53$ & (10) $4.16 \pm 1.16$ & (6) $6.97 \pm 3.29$ & (13) $4.99 \pm 1.13$ \\
\hline $5-\mathrm{CT}^{\mathrm{C}}$ & (16) $1.76 \pm 0.38$ & (10) $3.01 \pm 0.88$ & (6) $4.22 \pm 1.51$ & (13) $2.61 \pm 0.60$ \\
\hline \multicolumn{5}{|l|}{ IPSC } \\
\hline \multicolumn{5}{|l|}{ vmDR } \\
\hline Baseline & (6) $0.09 \pm 0.07$ & (15) $0.97 \pm 0.58$ & (15) $1.12 \pm 0.27$ & (8) $3.53 \pm 0.67$ \\
\hline $5-\mathrm{CT}^{\mathrm{C}}$ & (6) $0.00 \pm 0.00$ & (15) $0.33 \pm 0.14$ & (15) $0.78 \pm 0.26$ & (8) $2.76 \pm 0.59$ \\
\hline \multicolumn{5}{|l|}{ IwDR } \\
\hline Baseline & (5) $0.11 \pm 0.05$ & (15) $0.84 \pm 0.34$ & (12) $1.63 \pm 0.41$ & (14) $2.17 \pm 0.42$ \\
\hline $5-\mathrm{CT}^{\mathrm{c}}$ & (5) $0.02 \pm 0.02$ & (15) $0.39 \pm 0.17$ & (12) $0.78 \pm 0.23$ & (14) $1.65 \pm 0.33$ \\
\hline \multicolumn{5}{|l|}{ MR } \\
\hline Baseline & (7) $0.15 \pm 0.12$ & (14) $0.38 \pm 0.20$ & (13) $1.50 \pm 0.45$ & (5) $0.83 \pm 0.30$ \\
\hline $5-\mathrm{CT}$ & (7) $0.01 \pm 0.01$ & (14) $0.36 \pm 0.20$ & (13) $0.98 \pm 0.18$ & (5) $0.88 \pm 0.41$ \\
\hline
\end{tabular}

${ }^{a}$ Age $\times$ treatment interaction was significant; and asterisk indicates significant difference at a given age $\left(\operatorname{EPSC}: \mathrm{vmDR}, F_{(3,38)}=19.7, p=0.017 ; \operatorname{IwDR}, F_{(3,38)}=8.8, p<0.001\right)$.

${ }^{b}$ Treatment effect approached significance $(p=0.055)$.

Indicates a significant main effect of treatment $\left(5-\mathrm{CT}<\right.$ baseline; EPSC: MR, $F_{(1,41)}=20.05, p<0.001 ;$ IPSC: vmDR, $F_{(1,39)}=5.171, p=0.029 ;$ IwDR, $\left.F_{(1,42)}=13.84, p=0.001\right)$

\section{Morphological changes in developing raphe 5-HT neurons}

Biocytin included in the recording electrolyte efficiently fills recorded cells and is easily visualized using fluorescent-labeled streptavidin allowing for a detailed morphological analysis of the cell bodies and dendrites of recorded neurons from confocal xyz image stacks. Data presented here derive from a total of 127 filled and traced neurons in the vmDR $(\mathrm{P} 4=9, \mathrm{P} 12=12, \mathrm{P} 21=9$, $\mathrm{P} 60=19), \operatorname{lwDR}(\mathrm{P} 4=6, \mathrm{P} 12=9, \mathrm{P} 21=12, \mathrm{P} 60=12)$, and $\mathrm{MR}$ $(\mathrm{P} 4=7, \mathrm{P} 12=10, \mathrm{P} 21=13, \mathrm{P} 60=9)$. Generally, at P4 neurons within the DR had a circular appearance with highly branched dendrites that did not extend far from the soma (Fig. 7A). Interestingly, the number of primary branches was different between subfields, with vmDR having more than the lwDR and MR (Fig. $7 B$, subfield $\left.F_{(2,115)}=9.109, p<0.001\right)$. There was a trend toward higher numbers of primary branches at P4 and P12 compared with P21 and P60 (age: $F_{(3,115)}=2.52, p=0.06$ ). The primary branches became less branched with age, as illustrated by the decrease in the number of nodes or branch points (Fig. $7 C$; age: $\left.F_{(3,115)}=11.49, p<0.001\right)$. However, even though the number of nodes decreased with age, the vmDR and lwDR 5-HT neurons had more nodes at all ages, indicating increased branching of dendrites, than MR neurons (Fig. $7 C$; subfield: $F_{(2,115)}=13.46$, $p<0.001)$. Concomitant with the change in nodes in the vmDR and lwDR was a change in total dendritic length; neurons increased their total dendritic length between P4 and P21, and then decreased in length between P2 1 and P60 (Fig. 7D; age $\times$ subfield: $\left.F_{(6,115)}=2.59, p=0.02\right)$. The MR neurons do not appear to undergo the dendritic outgrowth seen in the vmDR and lwDR. Overall, these morphological results indicate that vmDR and lwDR neurons demonstrated a growth and extension of dendrites between P4 and P21 after which significant pruning occurred. A representative plot of the Scholl analysis of the dendritic arbors of vmDR neurons is shown in Figure $7 E$ and echoes the above results, demonstrating the expansion of dendritic length at distances further from the soma at $\mathrm{P} 12$ and $\mathrm{P} 21$ with a reduction by P60 (Fig. $7 E$; age $\times$ distance from center: $F_{(117,1833)}=3.59, p<$ 0.001 ). Similar results were seen in the lwDR (age $\times$ distance from center: $\left.F_{(117,1287)}=2.57, p<0.001\right)$ and MR (age $\times$ dis- tance from center: $\left.F_{(117,1092)}=1.82, p<0.001\right)$, although in the MR P4 was more similar to P12 and P21 (data not shown).

\section{5-HT and vGlut3 immunohistochemistry}

Another primary question asked was whether or not the Pet-1::YFP-labeled neurons actually produced 5-HT at P4 as they do prenatally and in adulthood (Scott et al., 2005; Hawthorne et al., 2010). Immunohistochemistry demonstrated that most $\mathrm{YFP}^{+}$cells also contained 5-HT at P4 (Fig. 8A). Quantitative analysis indicated that $82.6 \pm 1.1 \%$ of $\mathrm{YFP}^{+}$cells also expressed 5 -HT in the vmDR and $87.6 \pm 3.1 \%$ in the lwDR (mean \pm SEM; $n=4)$. In addition, previous studies have shown that in adulthood 5-HT colocalizes with the vesicular glutamate transporter vGlut3, especially in cells near the midline (Shutoh et al., 2008; Commons, 2009; Amilhon et al., 2010; Calizo et al., 2011). Importantly, this suggests the presence of releasable glutamate in 5-HT neurons. In this study, the examination of vGlut3 immunohistochemistry suggested that many, but not all, $\mathrm{YFP}^{+}$neurons also contain vGlut 3 early in development (Fig. $8 B$ ). Conversely, populations of vGlut3-immunoreactive neurons that do not contain 5-HT, as indicated by vGlut3 expression alone, appear to exist as well. Colocalization analysis of vGlut 3 with YFP in the brains of P4 pups indicated that $57.8 \pm 0.8 \%$ (mean $\pm \mathrm{SEM} ; n=3$ ) of $\mathrm{YFP}^{+}$neurons in the vmDR also contained vGlut 3 immunoreactivity. In contrast, only $7.5 \pm 1.1 \%$ of $\mathrm{YFP}^{+}$cells in the lwDR also contained vGlut3.

\section{Discussion}

The development of 5-HT neurons begins early in rats and mice with neurons undergoing their final division as early as E10, synthesizing 5-HT by E12-E14, and migrating into cell clusters resembling the adult raphe by birth (Altman and Bayer, 1981; Hawthorne et al., 2010). Even though the perinatal raphe resembles the adult raphe, we provide evidence that the physiological and morphological development of 5-HT neurons were immature shortly after birth, and cells developed mature characteristics in the second to third weeks following birth. Specifically, P4 5-HT neurons, especially in the 
vmDR and $l w D R$ subfields, displayed an immature phenotype marked by high excitability and low inhibition. This increased excitability was due to a depolarized RMP, increased membrane resistance, enhanced frequency of firing, no $5-\mathrm{HT}_{1 \mathrm{~A}}$ autoreceptor-mediated response, lack of GABAergic synaptic input, smaller GABA neuron number and innervation, and immature morphology. In contrast, MR neurons remained relatively unchanged during development. The late postnatal development of the DR could make it particularly susceptible to environmental perturbations, resulting in 5-HT system dysregulation and pathology.

\section{P4 serotonin neurons had hyperexcitable membrane characteristics}

One of the hallmarks of the P4 5-HT neuron physiology was the high RMP, indicating an increased conductance. Coincident with the change in resistance from P4 to P12 in the vmDR and lwDR was a hyperpolarization of the RMP. A possible explanation for these changes is a change in $\mathrm{K}^{+}$conductance. $\mathrm{K}_{2 \mathrm{P}}$ channels set the RMP in some neurons (Lesage and Lazdunski, 2000; Talley et al., 2003; Honoré, 2007; Enyedi and Czirjak, 2010). In adult 5-HT neurons, barium eliminates $\mathrm{K}^{+}$leak currents and depolarizes RMP (Päsler et al., 2007; Ma et al., 2011). In our study, the change in current and RMP in response to barium were larger at $\mathrm{P} 60$ than at $\mathrm{P} 4$. $\mathrm{K}_{2 \mathrm{P}}$ subunit expression differs across development in the cerebellum and dorsal root ganglion (Aller and Wisden, 2008; Kim et al., 2012) and could also be the case in the DR as $K_{2 P}$ channels are found in the adult DR (Washburn et al., 2002; Heurteaux et al., 2006). The developmental profile of $\mathrm{K}^{+}$leak channels in the DR is a promising avenue for future studies.

A likely result of a depolarized RMP and large membrane resistance is increased excitability. 5-HT neurons in the vmDR and lwDR at P4 fired more action potentials following depolarizing current injections than did neurons at later ages. The functional consequence of increased excitability is likely increased 5-HT release in forebrain target sites, which would be intensified at P4 by the depolarized threshold and increased duration of the action potential. Because vGlut3 colocalized with vmDR 5-HT neurons, increased glutamate release may accompany increased 5-HT release. Importantly, vGlut 3 has been shown to colocalize with 5 -HT fibers and terminals in several brain regions implicated in anxiety (Commons, 2009; Amilhon et al., 2010).

Higher 5-HT and glutamate output during the first few weeks of life could alter the organization of forebrain neural circuits
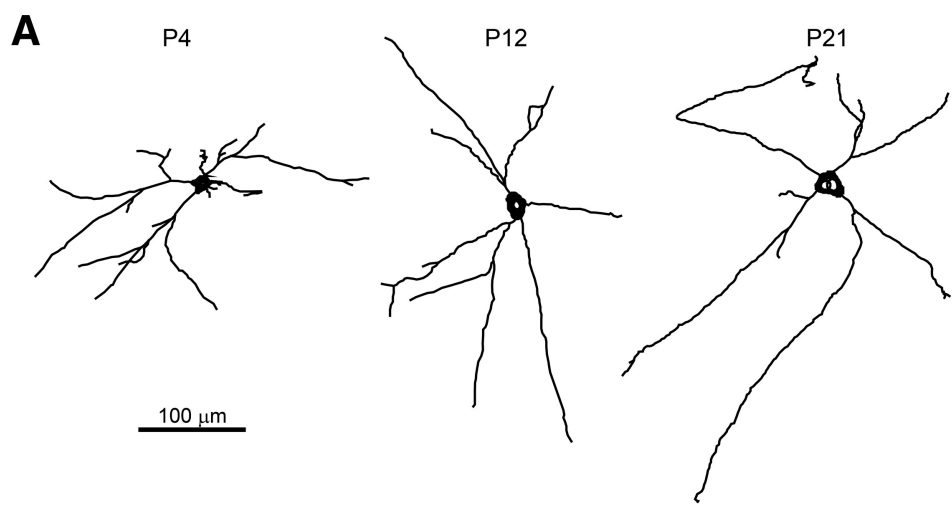

P60
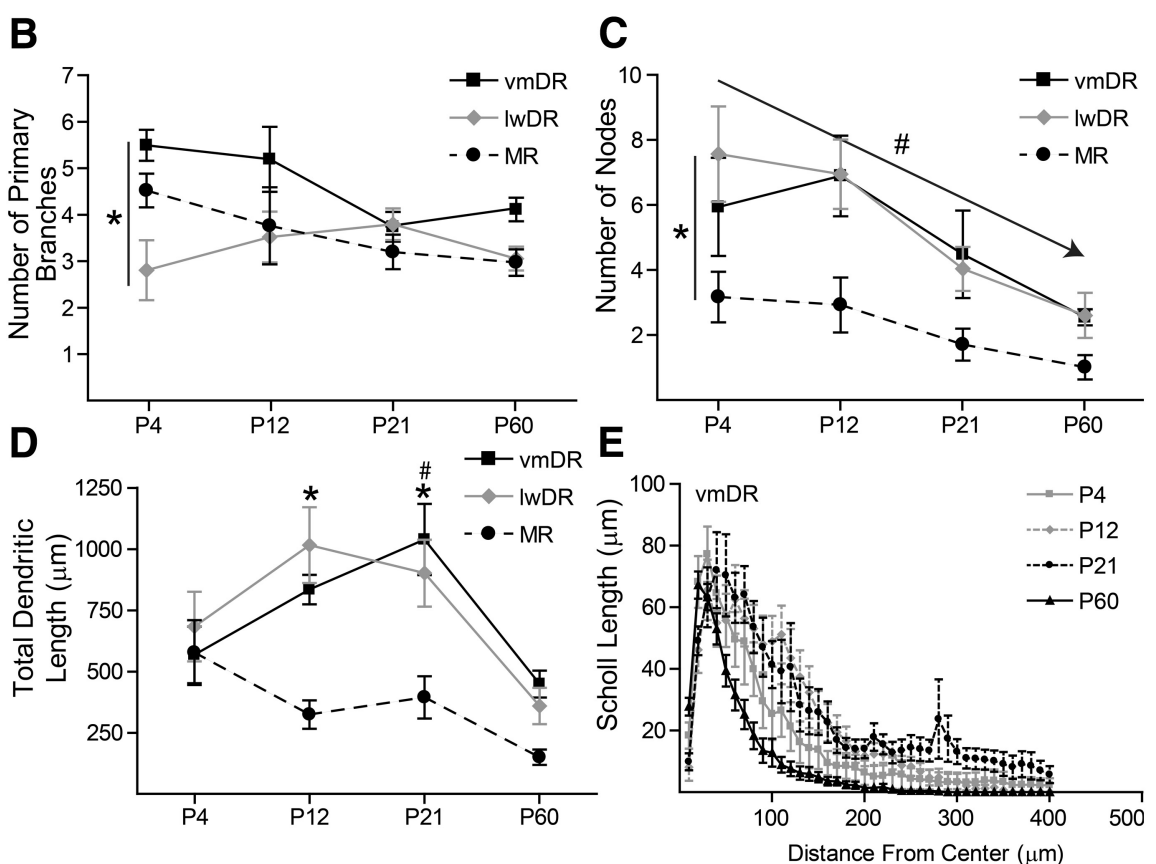

Figure 7. 5-HT neurons underwent a developmental change in morphology marked by increased outgrowth followed by significant pruning. $A$, Drawings from representative biocytin-filled vmDR 5-HT neurons from P4, P12, P21, and P60 animals. Scale bar, $100 \mu \mathrm{m} . \boldsymbol{B}$, Collapsed across age the number of primary branches was higher in the vmDR than the IwDR and MR (* ${ }^{*}$ ubfield: $\left.F_{(2,115)}=9.109, p<0.001\right)$. There was a trend toward decreased primary branches across age (age: $\left.F_{(3,115)}=2.52, p=0.06\right) . C$ 作 $P 60)$, but MR cells were less branched than either vmDR or IwDR cells ( ${ }^{*}$ subfield: $\left.F_{(2,115)}=13.46, p<0.001\right) . \boldsymbol{D}$, In vmDR and IwDR neurons, total dendritic length increased from $\mathrm{P} 4$ to $\mathrm{P} 12$ and $\mathrm{P} 21$, and then decreased significantly by $\mathrm{P} 60$ (age $\times$ subfield: is evident in the tracings in $\boldsymbol{A}$. Dendritic length did not change in the MR. $\boldsymbol{E}$, Scholl analysis of dendritic length from the center of the soma for vmDR cells shows the greater amount of length at points further from the cell in P21 animals (as illustrated in Fig. $6 \mathrm{~A}$ ) and, with the curve shifted to the left, the pruning or decrease in length that occurred by adulthood (age $\times$ distance from center: $\left.F_{(117,1833)}=3.59, p<0.001\right)$.

(Spitzer, 2006). In the cortex and hippocampus, before the second week of life, GABA works in concert with glutamate to enhance developmental processes (Ben-Ari et al., 1997; Ben-Ari, 2002; Leinekugel, 2003; Bortone and Polleux, 2009). Serotonin could modulate these effects since it is excitatory during this period through activation of $5-\mathrm{HT}_{7}$ and $5-\mathrm{HT}_{2}$ receptors (Béique et al., 2004; Benekareddy et al., 2010). Multiple studies have shown that the lack of 5-HT or 5-HT receptors during development alters neural circuitry development (Vitalis and Parnavelas, 2003; Sodhi and Sanders-Bush, 2004; Ferreira et al., 2010; Lesch and Waider, 2012). The time course of physiological development of 5-HT neurons and the potential developmental influence of 5-HT on forebrain targets represent points of vulnerability 

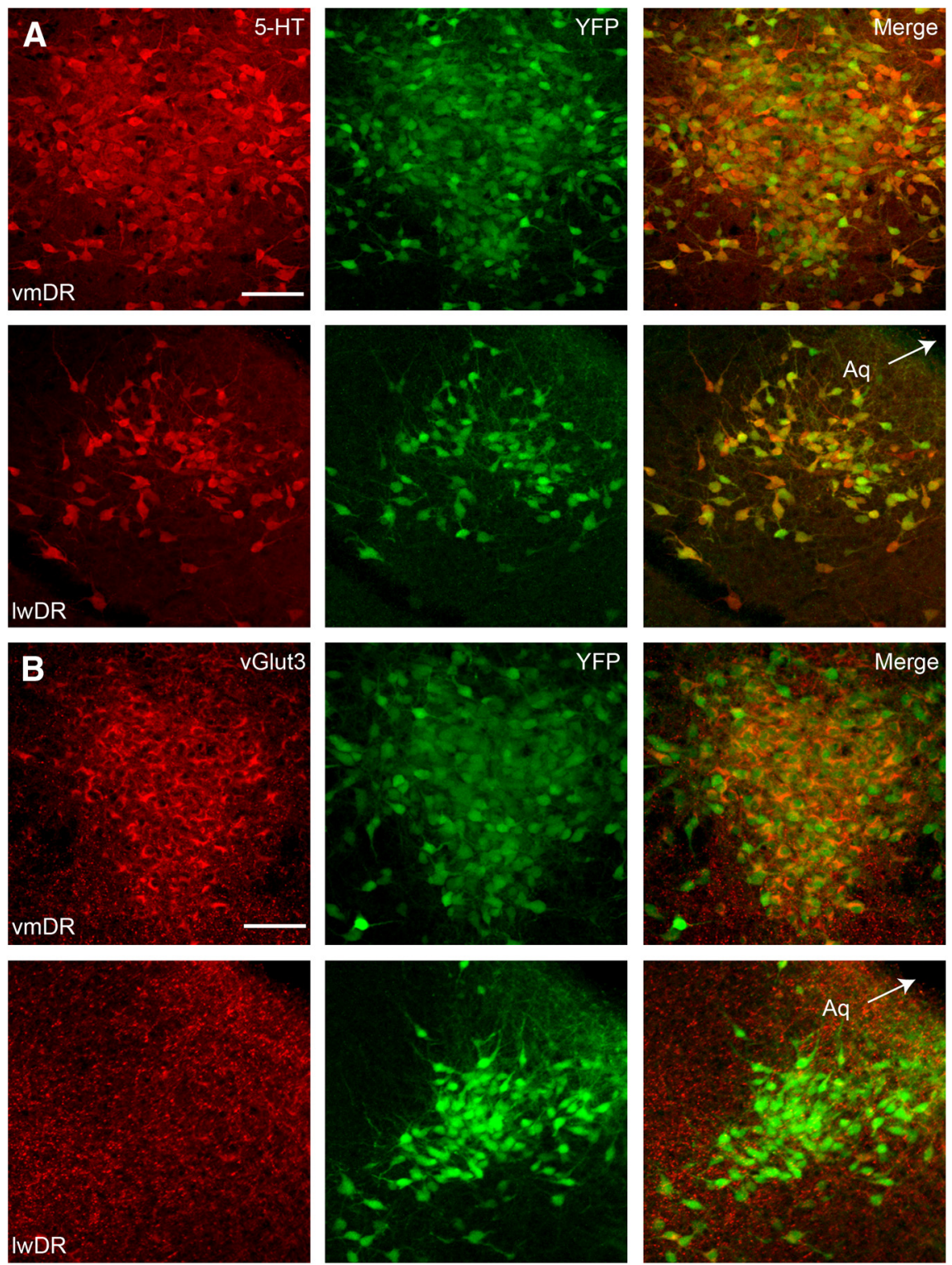

Figure 8. Dorsal raphe neurons produce both 5-HT and vGlut3 at P4. A, Photomicrographs show 5-HT immunofluorescence (red), Pet-1::YFP fluorescence (green), and a merged image of the vmDR and IwDR from a P4 mouse pup. Our data indicate that most Pet-1::YFP cells in both the vmDR $(\sim 83 \%)$ and IwDR $(\sim 88 \%)$ are making 5 -HT at P4. $\boldsymbol{B}$, Photomicrographs show vGlut3 immunofluorescence (red), Pet-1::YFP fluorescence (green), and a merged image of the vmDR and IwDR from a P4 mouse pup. Our data indicate that a majority of Pet-1::YFP cells also produce vGlut3 in the vmDR ( $\sim 57 \%)$, although few YFP cells in the IwDR ( $~ 8 \%)$ express vGlut3. Aq, Cerebral aqueduct Scale bars, $100 \mu \mathrm{m}$.

through which environmental influences could alter neural circuitry formation.

\section{Absence of auto-inhibition at P4}

Another major unexpected developmental change was the late appearance of the 5- $\mathrm{HT}_{1 \mathrm{~A}}$ autoreceptor-mediated response. This response was absent at $\mathrm{P} 4$ and was not present in all cells at P12 and P21. Absence of the GTP $\gamma \mathrm{S}$ response at P4 suggested that the effector mechanism was not functional. However, at P21, GTP $\gamma \mathrm{S}$ elicited an outward current in all cells tested, suggesting that the lack of $5-\mathrm{HT}_{1 \mathrm{~A}}$ response in some cells was due either to an absence of the $5-\mathrm{HT}_{1 \mathrm{~A}}$ receptor or a lack of receptor-effector coupling. These data are very important since P12-P21 is the critical period for $5-\mathrm{HT}_{1 \mathrm{~A}}$ influence on adult anxiety-related behavior (Lo Iacono and Gross, 2008;
Donaldson et al., 2014). Early life changes in expression patterns of 5-HT receptors are seen in other brain regions as well (Béïque et al., 2004; Goodfellow et al., 2009; Benekareddy et al., 2010). The lack of the $5-\mathrm{HT}_{1 \mathrm{~A}}$ receptormediated inhibition provides an additional source of excitability in the raphe during the first 2 postnatal weeks.

\section{Circuit integration of 5-HT neurons}

Another source of inhibition, $\mathrm{GABA}_{\mathrm{A}}{ }^{-}$ mediated postsynaptic currents, was absent at P4 and did not increase until P21. In contrast, EPSCs were present in all recorded neurons at $\mathrm{P} 4$, albeit at lower frequencies than at later ages. Immunohistochemical data suggested that at $\mathrm{P} 4$ the GABA system in the dorsal raphe is underdeveloped. GAD67-IR neurons were present at more rostral levels of the raphe in $\mathrm{P} 4$ pups but were rare in more caudal parts of the DR. In addition, the dense cluster of small puncta observed in the vmDR in adults was highly underdeveloped in $\mathrm{P} 4$ pups. Other fiber plexuses observed in more lateral regions of the adult appeared less dense at P4. The minute amount of IPSC activity in pups appeared to be due to the smaller number of GABA neurons and lack of GABA afferent input, indicating a lower inhibitory tone to 5-HT neurons early in development.

One likely explanation for the increased synaptic activity after $\mathrm{P} 4$ would be the formation and maturation of synaptic contacts during the first few weeks of life as the morphology of the 5-HT dendrites mature. Dendritic morphology of 5-HT neurons changed in concert with changes in PSC frequency. P4 neurons had many highly branched neurites that remained close to the soma. By P12 and P21, dendrites elongated away from the soma and reduced the number of branches. The $\mathrm{P} 4$ and P21 neurons had more branch points and longer dendrites than the adult 5-HT neurons, suggesting a process of outgrowth and pruning (Kasper et al., 1994). While there is little evidence as to what regulates the dendritic morphology of neurons in the dorsal raphe, dendrite outgrowth in other regions is under the control of both genetic and activity-dependent processes (Beutler et al., 2011; Srivastava et al., 2012; van der Velden et al., 2012).

\section{Regional differences}

As in previous reports in rats and mice, we observed regional differences between raphe subfields. The most notable differences occurred between the dorsal (vmDR and lwDR) and median raphe. Very surprisingly, neurons recorded from the MR did not show any developmental changes in RMP, excitability, EPSC activity, or dendrite morphology. In rats, one of the primary differences observed between the DR and MR was a lower 5- $\mathrm{HT}_{1 \mathrm{~A}}$ 
receptor-mediated response in MR 5-HT neurons (Beck et al., 2004). In mice, MR 5-HT neurons displayed a minimal response to 5-CT at all ages. The lack of 5- $\mathrm{HT}_{1 \mathrm{~A}}$ receptor auto-inhibition would likely increase the excitability of MR neurons, whereas DR neurons would inhibit their own firing. Although both DR and MR neurons express the transcription factor Pet-1 (Scott et al., 2005), which is required for TPH and 5- $\mathrm{HT}_{1 \mathrm{~A}}$ receptor expression in serotonin neurons, potential differences could arise from differential expression of other gene regulatory elements. Some differences between the MR and the DR may arise from differences in embryonic origin as the MR and DR mostly derive from different rhombomeres (Jensen et al., 2008; Alonso et al., 2013).

Differences between the lwDR and vmDR subfields were less substantial in terms of the developmental trajectory. The primary differences emerged when the neurons were recorded from adult mice; that is, larger membrane resistance, larger amplitude and duration APs and larger AHP amplitude in lwDR neurons. Similar findings from our laboratory have been previously reported (Crawford et al., 2010). We also previously reported that lwDR neurons had higher EPSC frequencies than vmDR neurons; that difference was also seen in this study, but as a trend (Crawford et al., 2011). The data presented here and in our previous studies indicate that the difference in neural characteristics between the MR and DR are more robust than between the vmDR and $l w D R$, particularly during development.

\section{Conclusions}

Our data indicate that a dynamic shift in neuronal excitability marked by decreased membrane excitability, increased $5-\mathrm{HT}_{1 \mathrm{~A}}$ auto-receptor inhibitory activity, and increased IPSC activity took place in the second and third weeks of life in 5-HT neurons of the DR, but less so in the MR. Altered excitability likely means altered patterns of serotonin release that would impact maturation in other brain regions where 5-HT is released and 5-HT receptors are expressed developmentally, such as the cortex and hippocampus. Finally, the numerous physiological and morphological changes we identified in 5-HT neurons may be points of vulnerability to outside stressors.

\section{References}

Agid O, Shapira B, Zislin J, Ritsner M, Hanin B, Murad H, Troudart T, Bloch M, Heresco-Levy U, Lerer B (1999) Environment and vulnerability to major psychiatric illness: a case control study of early parental loss in major depression, bipolar disorder and schizophrenia. Mol Psychiatry 4:163-172. CrossRef Medline

Aitken AR, Törk I (1988) Early development of serotonin-containing neurons and pathways as seen in wholemount preparations of the fetal rat brain. J Comp Neurol 274:32-47. CrossRef Medline

Aller MI, Wisden W (2008) Changes in expression of some two-pore domain potassium channel genes (KCNK) in selected brain regions of developing mice. Neuroscience 151:1154-1172. CrossRef Medline

Alonso A, Merchán P, Sandoval JE, Sánchez-Arrones L, Garcia-Cazorla A, Artuch R, Ferrán JL, Martínez-de-la-Torre M, Puelles L (2013) Development of the serotonergic cells in murine raphe nuclei and their relations with rhombomeric domains. Brain structure and function 218: 1229-1277. CrossRef Medline

Altman J, Bayer SA (1981) Development of the brain stem in the rat. V. Thymidine-radiographic study of the time of origin of neurons in the midbrain tegmentum. J Comp Neurol 198:677-716. CrossRef Medline

Amilhon B, Lepicard E, Renoir T, Mongeau R, Popa D, Poirel O, Miot S, Gras C, Gardier AM, Gallego J, Hamon M, Lanfumey L, Gasnier B, Giros B, El Mestikawy S (2010) VGluT3 (vesicular glutamate transporter type 3) contribution to the regulation of serotonergic transmission and anxiety. J Neurosci 30:2198-2210. CrossRef Medline

Andrade R, Nicoll RA (1987) Pharmacologically distinct actions of serotonin on single pyramidal neurones of the rat hippocampus recorded in vitro. J Physiol 394:99-124. Medline
Andrade R, Malenka RC, Nicoll RA (1986) A G protein couples serotonin and $\mathrm{GABAB}$ receptors to the same channels in hippocampus. Science 234:1261-1265. CrossRef Medline

Beck SG, Pan YZ, Akanwa AC, Kirby LG (2004) Median and dorsal raphe neurons are not electrophysiologically identical. J Neurophysiol 91:9941005. CrossRef Medline

Béique JC, Campbell B, Perring P, Hamblin MW, Walker P, Mladenovic L, Andrade R (2004) Serotonergic regulation of membrane potential in developing rat prefrontal cortex: coordinated expression of 5-hydroxytryptamine (5-HT) 1A, 5-HT2A, and 5-HT7 receptors. J Neurosci 24:4807-4817. CrossRef Medline

Ben-Ari Y (2002) Excitatory actions of gaba during development: the nature of the nurture. Nat Rev Neurosci 3:728-739. CrossRef Medline

Ben-Ari Y, Khazipov R, Leinekugel X, Caillard O, Gaiarsa JL (1997) GABAA, NMDA and AMPA receptors: a developmentally regulated "menage a trois." Trends Neurosci 20:523-529. CrossRef

Benekareddy M, Goodfellow NM, Lambe EK, Vaidya VA (2010) Enhanced function of prefrontal serotonin 5-HT(2) receptors in a rat model of psychiatric vulnerability. J Neurosci 30:12138-12150. CrossRef Medline

Beutler LR, Eldred KC, Quintana A, Keene CD, Rose SE, Postupna N, Montine TJ, Palmiter RD (2011) Severely impaired learning and altered neuronal morphology in mice lacking NMDA receptors in medium spiny neurons. PLoS One 6:e28168. CrossRef Medline

Bortone D, Polleux F (2009) KCC2 expression promotes the termination of cortical interneuron migration in a voltage-sensitive calcium-dependent manner. Neuron 62:53-71. CrossRef Medline

Calizo LH, Akanwa A, Ma X, Pan YZ, Lemos JC, Craige C, Heemstra LA, Beck SG (2011) Raphe serotonin neurons are not homogenous: electrophysiological, morphological and neurochemical evidence. Neuropharmacology 61:524-543. CrossRef Medline

Cameron WE, Núñez-Abades PA, Kerman IA, Hodgson TM (2000) Role of potassium conductances in determining input resistance of developing brain stem motoneurons. J Neurophysiol 84:2330-2339. Medline

Carr GV, Lucki I (2011) The role of serotonin receptor subtypes in treating depression: a review of animal studies. Psychopharmacology (Berl) 213: 265-287. CrossRef Medline

Commons KG (2009) Locally collateralizing glutamate neurons in the dorsal raphe nucleus responsive to substance $\mathrm{P}$ contain vesicular glutamate transporter 3 (VGLUT3). J Chem Neuroanat 38:273-281. CrossRef Medline

Crawford LK, Craige CP, Beck SG (2010) Increased intrinsic excitability of lateral wing serotonin neurons of the dorsal raphe: a mechanism for selective activation in stress circuits. J Neurophysiol 103:2652-2663. CrossRef Medline

Crawford LK, Craige CP, Beck SG (2011) Glutamatergic input is selectively increased in dorsal raphe subfield 5-HT neurons: role of morphology, topography and selective innervation. Eur J Neurosci 34:1794-1806. CrossRef Medline

De Bellis MD, Thomas LA (2003) Biologic findings of post-traumatic stress disorder and child maltreatment. Current psychiatry reports 5:108-117. CrossRef Medline

De Bellis MD, Keshavan MS, Clark DB, Casey BJ, Giedd JN, Boring AM, Frustaci K, Ryan ND (1999) A.E. Bennett Research Award. Developmental traumatology. Part II: brain development. Biol Psychiatry 45: 1271-1284. CrossRef Medline

Donaldson ZR, Piel DA, Santos TL, Richardson-Jones J, Leonardo ED, Beck SG, Champagne FA, Hen R (2014) Developmental effects of serotonin $1 \mathrm{~A}$ autoreceptors on anxiety and social behavior. Neuropsychopharmacology 39:291-302. CrossRef Medline

Enyedi P, Czirják G (2010) Molecular background of leak K+ currents: two-pore domain potassium channels. Physiol Rev 90:559-605. CrossRef Medline

Ferreira TA, Iacono LL, Gross CT (2010) Serotonin receptor 1A modulates actin dynamics and restricts dendritic growth in hippocampal neurons. Eur J Neurosci 32:18-26. CrossRef Medline

Fremeau RT Jr, Burman J, Qureshi T, Tran CH, Proctor J, Johnson J, Zhang H, Sulzer D, Copenhagen DR, Storm-Mathisen J, Reimer RJ, Chaudhry FA, Edwards RH (2002) The identification of vesicular glutamate transporter 3 suggests novel modes of signaling by glutamate. Proc Natl Acad Sci U S A 99:14488-14493. CrossRef Medline

Goodfellow NM, Benekareddy M, Vaidya VA, Lambe EK (2009) Layer II/III 
of the prefrontal cortex: inhibition by the serotonin $5-\mathrm{HT}_{1 \mathrm{~A}}$ receptor in development and stress. J Neurosci 29:10094-10103. CrossRef Medline

Hawthorne AL, Wylie CJ, Landmesser LT, Deneris ES, Silver J (2010) Serotonergic neurons migrate radially through the neuroepithelium by dynamin-mediated somal translocation. J Neurosci 30:420-430. CrossRef Medline

Hendricks TJ, Fyodorov DV, Wegman LJ, Lelutiu NB, Pehek EA, Yamamoto B, Silver J, Weeber EJ, Sweatt JD, Deneris ES (2003) Pet-1 ETS gene plays a critical role in 5-HT neuron development and is required for normal anxiety-like and aggressive behavior. Neuron 37:233-247. CrossRef Medline

Heurteaux C, Lucas G, Guy N, El Yacoubi M, Thümmler S, Peng XD, Noble F, Blondeau N, Widmann C, Borsotto M, Gobbi G, Vaugeois JM, Debonnel G, Lazdunski M (2006) Deletion of the background potassium channel TREK-1 results in a depression-resistant phenotype. Nat Neurosci 9:1134-1141. CrossRef Medline

Honoré E (2007) The neuronal background K2P channels: focus on TREK1. Nat Rev Neurosci 8:251-261. CrossRef Medline

Jensen P, Farago AF, Awatramani RB, Scott MM, Deneris ES, Dymecki SM (2008) Redefining the serotonergic system by genetic lineage. Nat Neurosci 11:417-419. CrossRef Medline

Kasper EM, Lübke J, Larkman AU, Blakemore C (1994) Pyramidal neurons in layer 5 of the rat visual cortex. III. Differential maturation of axon targeting, dendritic morphology, and electrophysiological properties. J Comp Neurol 339:495-518. CrossRef Medline

Kessler RC, Chiu WT, Demler O, Merikangas KR, Walters EE (2005) Prevalence, severity, and comorbidity of 12-month DSM-IV disorders in the National Comorbidity Survey Replication. Arch Gen Psychiatry 62:617627. CrossRef Medline

Kim GT, Cho YW, Tak HM, Lee JS, Kim EJ, Han J, Kang D (2012) Agerelated changes in two-pore domain acid-sensitive $\mathrm{K}(+)$ channel expression in rat dorsal root ganglion neurons. Clinical and experimental pharmacology and physiology 39:43-48. CrossRef Medline

Koen N, Stein DJ (2011) Pharmacotherapy of anxiety disorders: a critical review. Dialogues Clin Neurosci 13:423-437. Medline

Leinekugel X (2003) Developmental patterns and plasticities: the hippocampal model. J Physiol Paris 97:27-37. CrossRef Medline

Lemos JC, Pan YZ, Ma X, Lamy C, Akanwa AC, Beck SG (2006) Selective 5-HT receptor inhibition of glutamatergic and GABAergic synaptic activity in the rat dorsal and median raphe. Eur J Neurosci 24:3415-3430. CrossRef Medline

Lemos JC, Zhang G, Walsh T, Kirby LG, Akanwa A, Brooks-Kayal A, Beck SG (2011) Stress-hyperresponsive WKY rats demonstrate depressed dorsal raphe neuronal excitability and dysregulated CRF-mediated responses. Neuropsychopharmacology 36:721-734. CrossRef Medline

Lesage F, Lazdunski M (2000) Molecular and functional properties of twopore-domain potassium channels. Am J Physiol Renal Physiol 279:F793F801. Medline

Lesch KP, Waider J (2012) Serotonin in the modulation of neural plasticity and networks: implications for neurodevelopmental disorders. Neuron 76:175-191. CrossRef Medline

Lidov HG, Molliver ME (1982) Immunohistochemical study of the development of serotonergic neurons in the rat CNS. Brain Res Bull 9:559604. CrossRef Medline

Liu RJ, Lambe EK, Aghajanian GK (2005) Somatodendritic autoreceptor regulation of serotonergic neurons: dependence on L-tryptophan and tryptophan hydroxylase-activating kinases. Eur J Neurosci 21:945-958. CrossRef Medline

Lo Iacono L, Gross C (2008) Alpha- $\mathrm{Ca}^{2+} /$ calmodulin-dependent protein kinase II contributes to the developmental programming of anxiety in serotonin receptor 1A knock-out mice. J Neurosci 28:6250-6257. CrossRef Medline

Ma XY, Yu JM, Zhang SZ, Liu XY, Wu BH, Wei XL, Yan JQ, Sun HL, Yan HT,
Zheng JQ (2011) External Ba2+ block of the two-pore domain potassium channel TREK-1 defines conformational transition in its selectivity filter. J Biol Chem 286:39813-39822. CrossRef Medline

Marinelli S, Schnell SA, Hack SP, Christie MJ, Wessendorf MW, Vaughan CW (2004) Serotonergic and nonserotonergic dorsal raphe neurons are pharmacologically and electrophysiologically heterogeneous. J Neurophysiol 92:3532-3537. CrossRef Medline

Migliarini S, Pacini G, Pelosi B, Lunardi G, Pasqualetti M (2013) Lack of brain serotonin affects postnatal development and serotonergic neuronal circuitry formation. Mol Psychiatry 18:1106-1118. CrossRef Medline

Okuhara DY, Beck SG (1998) Corticosteroids alter 5-hydroxytryptamine1A receptor-effector pathway in hippocampal subfield CA3 pyramidal cells. J Pharmacol Exp Ther 284:1227-1233. Medline

Päsler D, Gabriel S, Heinemann U (2007) Two-pore-domain potassium channels contribute to neuronal potassium release and glial potassium buffering in the rat hippocampus. Brain Res 1173:14-26. CrossRef Medline

Ramboz S, Oosting R, Amara DA, Kung HF, Blier P, Mendelsohn M, Mann JJ, Brunner D, Hen R (1998) Serotonin receptor 1A knockout: an animal model of anxiety-related disorder. Proc Natl Acad Sci U S A 95:1447614481. CrossRef Medline

Richardson-Jones JW, Craige CP, Guiard BP, Stephen A, Metzger KL, Kung HF, Gardier AM, Dranovsky A, David DJ, Beck SG, Hen R, Leonardo ED (2010) 5-HT1A autoreceptor levels determine vulnerability to stress and response to antidepressants. Neuron 65:40-52. CrossRef Medline

Scott MM, Wylie CJ, Lerch JK, Murphy R, Lobur K, Herlitze S, Jiang W, Conlon RA, Strowbridge BW, Deneris ES (2005) A genetic approach to access serotonin neurons for in vivo and in vitro studies. Proc Natl Acad Sci U S A 102:16472-16477. CrossRef Medline

Shutoh F, Ina A, Yoshida S, Konno J, Hisano S (2008) Two distinct subtypes of serotonergic fibers classified by co-expression with vesicular glutamate transporter 3 in rat forebrain. Neurosci Lett 432:132-136. CrossRef Medline

Sodhi MS, Sanders-Bush E (2004) Serotonin and brain development. International review of neurobiology 59:111-174. CrossRef Medline

Spitzer NC (2006) Electrical activity in early neuronal development. Nature 444:707-712. CrossRef Medline

Srivastava DP, Woolfrey KM, Jones KA, Anderson CT, Smith KR, Russell TA, Lee H, Yasvoina MV, Wokosin DL, Ozdinler PH, Shepherd GM, Penzes P (2012) An autism-associated variant of Epac2 reveals a role for Ras/ Epac2 signaling in controlling basal dendrite maintenance in mice. PLoS Biol 10:e1001350. CrossRef Medline

Talley EM, Sirois JE, Lei Q, Bayliss DA (2003) Two-pore-Domain (KCNK) potassium channels: dynamic roles in neuronal function. Neuroscientist 9:46-56. CrossRef Medline

van der Velden L, van Hooft JA, Chameau P (2012) Altered dendritic complexity affects firing properties of cortical layer $2 / 3$ pyramidal neurons in mice lacking the 5-HT3A receptor. J Neurophysiol 108:1521-1528. CrossRef Medline

Vandermaelen CP, Aghajanian GK (1983) Electrophysiological and pharmacological characterization of serotonergic dorsal raphe neurons recorded extracellularly and intracellularly in rat brain slices. Brain Res 289:109-119. CrossRef Medline

Vitalis T, Parnavelas JG (2003) The role of serotonin in early cortical development. Dev Neurosci 25:245-256. CrossRef Medline

Wallace JA, Lauder JM (1983) Development of the serotonergic system in the rat embryo: an immunocytochemical study. Brain Res Bull 10:459479. CrossRef Medline

Washburn CP, Sirois JE, Talley EM, Guyenet PG, Bayliss DA (2002) Serotonergic raphe neurons express TASK channel transcripts and a TASK-like $\mathrm{pH}$ - and halothane-sensitive $\mathrm{K}^{+}$conductance. J Neurosci 22:1256-1265. Medline 